\title{
Cheirolepidiacean foliage and pollen from Cretaceous high-latitudes of southeastern Australia
}

\author{
Anne-Marie P. Tosolini ${ }^{\mathrm{a}, \mathrm{b}, *}$, Stephen McLoughlin ${ }^{\mathrm{a}, \mathrm{c}}$, Barbara E. Wagstaff ${ }^{\mathrm{b}}$, \\ David J. Cantrill ${ }^{\mathrm{d}}$, Stephen J. Gallagher ${ }^{\mathrm{b}}$ \\ a School of Botany, The University of Melbourne, Victoria 3010, Australia \\ b School of Earth Sciences, The University of Melbourne, Victoria 3010, Australia \\ c Department of Palaeobiology, The Swedish Museum of Natural History, Box 50007, S-104 05 Stockholm, Sweden

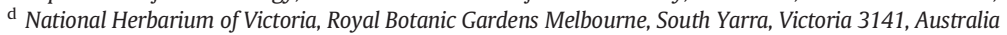

\section{A R T I C L E I N F O}

\section{Article history:}

Received 21 August 2013

Received in revised form 14 November 2013

Accepted 15 November 2013

Available online 18 December 2013

\section{Keywords:}

Cretaceous

Australia

Conifer

Cheirolepidiaceae

Classopollis

\begin{abstract}
A B S T R A C T
Cheirolepidiaceae leaves and pollen are recorded from Valanginian-Albian strata of southeastern Australia that were deposited at high-latitudes under cool, moist climates in contrast to the semi-arid or coastal habitats preferred by many northern Gondwanan and Laurasian representatives of this group. Leaves of this family are characterized by thick cuticles and cyclocytic stomata with randomly oriented apertures, arranged in scattered or longitudinal rows or bands. Stomata are deeply sunken and surrounded by four to six subsidiary cells that bear one or two ranks of prominent overarching papillae, which may constrict the mouth of the pit. Three new taxa (Otwayia denticulata Tosolini, Cheirolepidiaceae cuticle sp. A and sp. B) are distinguished based on cuticular features, adding to several previously documented cheirolepid conifers in the Early Cretaceous of eastern Australia. Cheirolepidiaceae foliage is preserved predominantly in fluvial floodbasin settings and is interpreted to be derived from small trees occupying disturbed or low-nutrient sites. The foliage is associated with Classopollis/ Corollina pollen and roots characterized by prominent mycorrhizal nodules. A Cenomanian Classopollis type recognised from Bathurst Island, Northern Australia, is recorded for the first time from the Early Cretaceous Eumeralla Formation, Otway Basin. Classopollis locally is rare in Valanginian-Barremian strata of Boola Boola, Gippsland, but constitutes up to $14 \%$ of the palynomorph assemblage in Albian strata. This indicates that the family was locally abundant in cool southern high-latitude climates of the Mesozoic, contrary to previous reports of its rarity in this region.
\end{abstract}

(c) 2013 International Association for Gondwana Research. Published by Elsevier B.V. All rights reserved.

\section{Introduction}

The extinct conifer family Cheirolepidiaceae has not previously been considered a major constituent of Early Cretaceous floras of southeastern Australia (Fig. 1), or other parts of Gondwana (Dettmann, 1994; Cantrill and Poole, 2005; Quattrocchio et al., 2011). However, in lower palaeolatitudes of the mid-Mesozoic, the family was represented by a diversity unparalleled in any other conifer family (Alvin, 1982; Watson, 1988). Fossil remains of this family first appear in the Late Triassic of western North America (Ash, 1973; Watson, 1988; Axsmith et al., 2004a). In Gondwana, the distinctive pollen of this family (attributed to Classopollis or Corollina) has been recorded from the Mesozoic of Antarctica (Late Cretaceous, Askin, 1992), South America (Jurassic,

\footnotetext{
is This article belongs to the Special Issue on Gondwanan Mesozoic biotas and bioevents.

* Corresponding author at: School of Earth Sciences, The University of Melbourne, Victoria 3010, Australia. Tel.: +613 8344 7675; fax: +6138344 7761.

E-mail addresses: a.tosolini@unimelb.edu.au (A.-M.P. Tosolini),

steve.mcloughlin@nrm.se (S. McLoughlin), wagstaff@unimelb.edu.au (B.E. Wagstaff),

David.Cantrill@rbg.vic.gov.au (D.J. Cantrill), sjgall@unimelb.edu.au (S.J. Gallagher).
}

Volkheimer et al., 2008; Cretaceous e.g. Perez Loinaze et al., 2012), Africa (Jurassic-Cretaceous, Msaky, 2011; Cretaceous, Gomez et al., 2002a; Bamford, 2004) and Australia (Late Triassic to Cretaceous, Helby et al., 1987). However, in contrast to this widespread distribution of pollen, macrofossils attributed to this family from southern high-latitudes are equivocal and sparse (Villar de Seoane, 1998) or not preserved in some major floras (Cantrill and Falcon Lang, 2001; Cantrill and Poole, 2002, 2005). In most areas, the family disappeared at the Cretaceous-Paleogene (K-Pg) boundary (van der Ham et al., 2003) but recent studies suggest that some representatives survived locally and briefly flourished at high palaeolatitudes (Argentina) in the aftermath of the end-Cretaceous biotic crisis (Barreda et al., 2012). This persistence of typical Mesozoic conifers into the Paleogene is consistent with the survival of relictual populations of other gymnosperms beyond the $\mathrm{K}-\mathrm{Pg}$ transition at various high-latitude sites (Carpenter and Hill, 1999; McLoughlin et al., 2008; Cúneo et al., 2010; McLoughlin et al., 2011).

Cheirolepidiaceae has a complex nomenclatural history (Watson, 1988) and has alternatively been named Cheirolepidaceae (Takhtajan, 1963; Paclt, 2011) and Hirmeriellaceae (Maheshwari, 2005). Two 


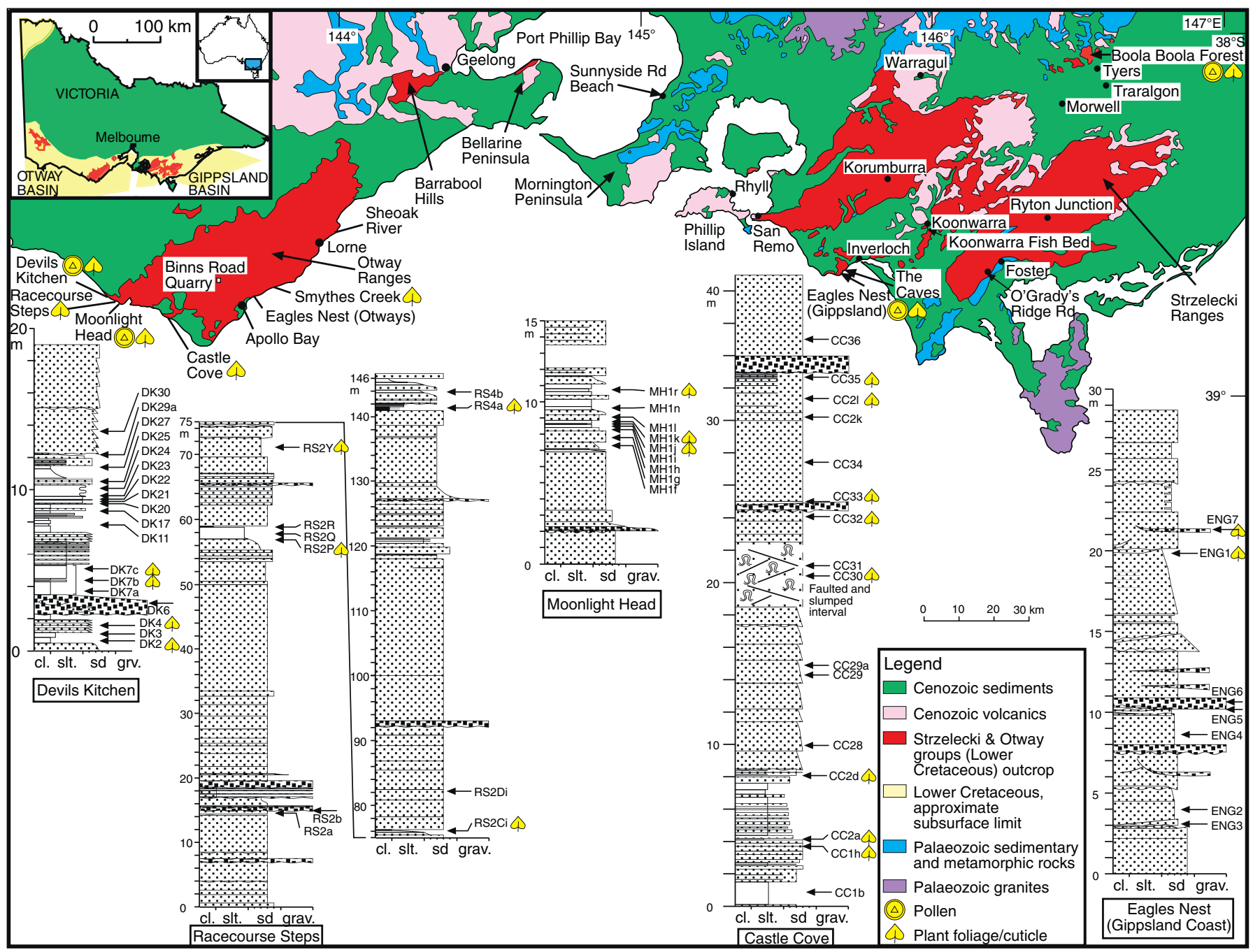

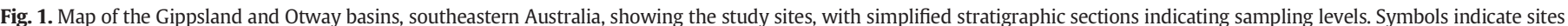
where Cheirolepidiacean pollen and plant foliage and/or cuticle was found.

main groups of Cheirolepidiaceae are generally recognized based on differences in their shoot morphology: the so-called frenelopsids and nonfrenelopsids. Frenelopsids have predominantly a whorled phyllotaxis and the representative genera (e.g., Frenelopsis and Pseudofrenelopsis) are found mainly in Laurasia (Alvin et al., 1981; Alvin, 1982; Francis, 1983; Watson, 1988; Clement-Westerhof and van Konijnenburg-van Cittert, 1991; Zhou, 1995; Guignard et al., 1998; Watson and Alvin, 1999; Daviero et al., 2001; Gomez et al., 2002b; Axsmith, 2006; Yang et al., 2006; Mendes et al., 2010; Bartiromo et al., 2012), but a few are also known from Gondwana (Watson, 1983; Kunzmann et al., 2006; Sucerquia et al., 2008). The non-frenelopsids have leaves borne in a spiral arrangement and include representatives of genera such as Brachyphyllum (Watson, 1988; Du et al., 2013) and Watsoniocladus (Srinivasan, 1995) from Laurasia, and Tomaxellia and Tarphyderma (Archangelsky, 1963, 1966, 1968; Archangelsky and Taylor, 1986, 1991; Villar de Seoane, 1998; Kunzmann et al., 2006) from Gondwana. Microsporangiate and ovuliferous cones attached to shoots or associated with leaves of both groups (Alvin et al., 1978, 1994; Kvaček, 2000; Axsmith et al., 2004b; Rothwell et al., 2007; del Fueyo et al., 2008; Escapa et al., 2012, 2013), contain Classopollis pollen (synonyms: Corollina, Circulina, Gliscopollis; Traverse, 2004). The distinctive spherical pollen with a ring-like germinal groove is the most diagnostic character of the family (Taylor and Alvin, 1984; Watson, 1988).
Pole (2000) first recognized cheirolepidiacean foliage and leafy shoots in Australia based on awl-shaped leaves bearing cuticles with diagnostic strongly sunken stomata and prominently papillate subsidiary cells from the Eromanga Basin, northeastern Australia. Pole (2000) assigned this material to Otwayia, a non-frenelopsid cheirolepid. The southeastern Australian Otway and Gippsland basins host the richest Cretaceous floras in Australia and have been well documented for over a century (e.g. Seward, 1904; Medwell, 1954a,b; Douglas, 1969, 1973; Drinnan and Chambers, 1986; Cantrill, 1991, 1992; McLoughlin et al., 2002). These floras of Valanginian-Albian age incorporate a broad array of equisetaleans, lycophytes, ferns, bennettitaleans, conifers, ginkgoaleans, early angiosperms and other seed plants. Awl-leafed conifers have been reported from several assemblages in these basins but the affinities of such fossils have remained equivocal. Awl-leafed conifer foliage is particularly abundant in Albian strata at two Otway Basin localities known as Racecourse Steps and Devils Kitchen (see Douglas, 1969 for locality details). The dominant small conifer leaves at these sites were originally assigned to the morphotaxon Geinitzia tetragona Cantrill and Douglas, 1988 but were transferred to Otwayia by Pole (2000), who inferred their cheirolepidiacean affinities.

Classopollis pollen is abundant in Lower Cretaceous strata of the Eromanga Basin (Burger, 1993) and is present, though generally considered to be less common, in southeastern Australian basins (Dettmann, 
1992). In the Australian succession, Classopollis reaches greatest abundance in the Early Jurassic (Helby et al., 1987), becoming rare later in that period but increasing again in the mid-Cretaceous (Douglas, 1985).

Cheirolepidiacean ecology can only be inferred from fossil remains. The family probably included plants with a range of habits (small shrubs to trees; Watson, 1988; Axsmith, 2006). Early studies from Laurasia highlighted their diminutive leaves, strong stomatal protection and common association with sediments of semi-arid or coastal environments, or to areas subject to repeated volcanic ash fall, in inferring that these xeromorphic plants were adapted to dry, saline or disturbed habitats (Vakhrameev, 1970; Watson, 1977; Upchurch and Doyle, 1981; Alvin, 1982; Francis, 1983, 1984; Archangelsky and Taylor, 1986; Watson, 1988). More recent studies indicate that the plants occupied a wider variety of environments (Gomez et al., 2002b; Mendes et al., 2010) but their full environmental tolerances remain poorly constrained. The distinctive pollen assigned to Classopollis is more characteristic of low-latitude megathermal-mesothermal palynoprovinces than higher latitude (temperate) settings during the Cretaceous (Alvin, 1982; Dettmann, 1992).

\section{Geological setting}

Palaeomagnetic data indicate that southeastern Australia was situated at high latitudes (c. $70-85^{\circ} \mathrm{S}$ ) during the Early Cretaceous (Fig. 1 ). Sedimentary successions of this age in the Gippsland, Bass and Otway basins, Victoria, incorporate important reference sections for several of the Australian Cretaceous palynostratigraphic (Helby et al., 1987; Morgan et al., 1995; Wagstaff et al., 2012) and phytostratigraphic zones (Douglas, 1969; Cantrill and Webb, 1987; Tosolini et al., 2002; Fig. 2). Sedimentation began contemporaneously in these basins during the latest Jurassic to Hauterivian in association with initial rifting between Australia and Antarctica (Lowry, 1988; Featherstone et al., 1991). Deposition of the Tyers Conglomerate (Gippsland Basin; Tosolini et al., 1999), and Casterton Formation and Crayfish Subgroup (Otway Basin; Duddy, 2003) occurred during this initial phase of extension. Lower Cretaceous strata distributed in outcrop and in the subsurface across the Mornington Peninsula basement ridge demonstrate that sedimentation was continuous between these basins from an early stage (Edwards and Baker, 1943; Douglas, 1969; Mallett and Holdgate, 1985), and the nature of the stratigraphic successions and distribution of unconformities indicate that these basins share very similar Cretaceous-Cenozoic tectonic and depositional histories (Lowry and Longley, 1991; K.A. Hill et al., 1995; Duddy, 2003; Fig. 2). During the ?Barremian-Albian, continued extension and a major influx of volcanogenic sediments from the east caused crustal loading and subsidence accommodating deposition of the plant-fossil-rich Eumeralla Formation in the Otway Basin and upper Strzelecki Group (the informal ‘Wonthaggi formation') in the Gippsland Basin (K.A. Hill et al., 1995; Bryan et al., 1997). Younger Cretaceous and Cenozoic, predominantly marine deposits, blanket these plant-rich strata throughout most of the Otway and Gippsland basins such that Early Cretaceous strata are exposed in only a few areas (Fig. 1).

The pre-Barremian units are represented by diverse facies associations characteristic of alluvial fan to braided fluvial (alluvial valley) deposits (Tosolini et al., 1999). The post-Barremian deposits are dominated by thick volcaniclastic sandstone sheets with westerly palaeocurrent indices deposited in braided fluvial channels. Unconformities at the top of both the Otway and Strzelecki groups correspond to a Cenomanian depositional hiatus (Norvick et al., 2001) linked to the opening of the Southern Ocean (Gleadow and Duddy, 1981; K.A. Hill et al., 1995; Duddy, 2003; Green et al., 2004). A second phase of rapid subsidence during the Turonian to early Campanian has been attributed to rifting (northeastsouthwest extension) between Australia and the Zealandia block (Veevers et al., 1991; K.C. Hill et al., 1995; Norvick et al., 2001) and accommodated deposition of the overlying Upper Cretaceous Golden Beach Group (Gippsland Basin) and Sherbrook Group (Otway Basin). These Upper Cretaceous strata are in turn mostly covered by a thick veneer of younger (Cenozoic) deposits.

\section{Materials and methods}

Macrofossils were systematically collected from key coastal cliff, stream and road cutting exposures of Lower Cretaceous strata in both the Gippsland and Otway basins (Tosolini, 2001). Sections were selected where previous palynological studies had provided some biostratigraphic

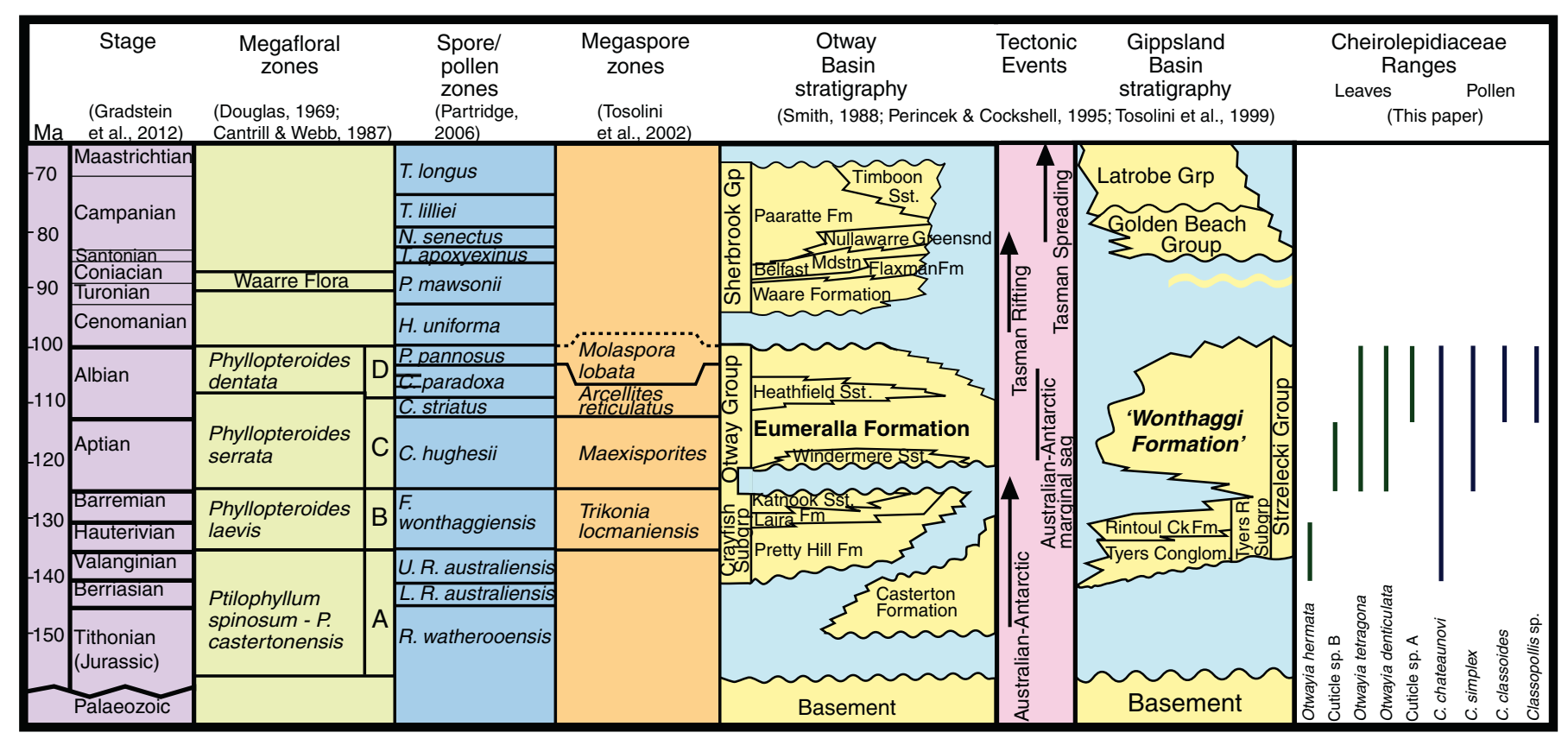

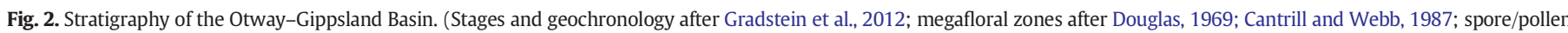

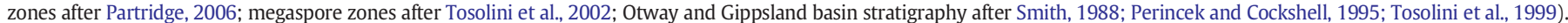


controls on the deposits (see Dettmann, 1963, 1986; Wagstaff and McEwen Mason, 1989; Wagstaff et al., 1997; Ferguson et al., 1999), and where past studies had indicated palaeontologically productive successions (Douglas, 1969, 1973). The authors collected most specimens but additional material held by Museum Victoria and the Geological Survey of Victoria (mostly collected in the 1960s by Dr J. Douglas) was also examined. All specimens illustrated in this study are now housed in the palaeobotanical collections of Museum Victoria and their registration numbers are prefixed 'MVP'.

Macrofossils were prepared using the standard dégagement technique of Fairon-Demaret et al. (1999). Cuticle was obtained from macrofossils by degauging a portion of a leaf with a scalpel and removing adhering sediment by immersion of the fragment in $48 \%$ hydrofluoric acid for $24 \mathrm{~h}$ at room-temperature. Leaf fragments were then immersed in $60 \% \mathrm{HNO}_{3}$ or $10-30 \% \mathrm{CrO}_{3}$ for periods of $10 \mathrm{~min}$ to $4 \mathrm{~h}$ to dissolve the coalified mesophyll tissues. In some cases, the leaf fragments were soaked in a catalyst $(\mathrm{NaOH})$ for a few minutes to a few hours before treatment with acid to assist removal of coally residues. The remaining cuticle was then rinsed in distilled water and mounted under a coverslip on a microscope slide for transmitted light microscopy or placed on an aluminium stub and coated in gold for scanning electron microscopy (Philips field emission gun SEM). Additional leaf cuticles were obtained by bulk maceration of $100-200 \mathrm{~g}$ sediment samples following the method of Wellman and Axe (1999). Measurements of mesofossils were obtained from SEM images rather than from specimens mounted in glycerine jelly.

Palynological samples from Eagles Nest (Gippsland coast) and Paradise Creek were collected in 1991 and processed by Laola Pty Ltd. (no longer operational) in Western Australia using standard processing techniques involving acid digestion ( $\mathrm{HCl}, \mathrm{HF})$, heavy liquid separation, oxidation and sieving at $10 \mu \mathrm{m}$. The samples from Devils Kitchen, Racecourse Steps and Moonlight Head were collected in 2011 and processed by Global Geolab in Canada using acid digestion $(\mathrm{HCl}, \mathrm{HF})$, heavy liquid separation and oxidation using Schulze solution. No sieving step was undertaken in the latter samples because it was felt that this processing step might have contributed to the lack of widely recorded angiosperms (which have small pollen) in Lower Cretaceous strata in Victoria (Wagstaff et al., 2012). Classopollis specimens were recorded by scanning two entire slides for each sample at $\times 200$ magnification; each Classopollis grain encountered was then examined at high power $\times 1000$.

\section{Systematic palaeobotany}

\subsection{Macrofossils and dispersed cuticle}

Family Cheirolepidiaceae Takhtajan, 1963

Genus Otwayia Pole, 2000

Type species: Otwayia tetragona (Cantrill and Douglas) Pole, 2000; Eumeralla Formation; Albian; Otway Basin, Victoria, Australia.

Otwayia tetragona (Cantrill and Douglas) Pole, 2000 (Figs. 3A, C; $4 \mathrm{~A}-\mathrm{M})$

1988 Geinitzia tetragona Cantrill and Douglas, p. 263, Figs. 12, 13.

2000 Otwayia tetragona Pole, p. 177, Fig. 18.

Material examined: Twenty specimens examined (see Tosolini, 2001). Museum Victoria specimen numbers: macrofossils MVP210476 and MVP210478; mesofossils on SEM stubs MVP210411, MVP210419MVP210430, MVP210434-MVP210436 inclusive.

Description: Leafy twigs, isolated leaves and cuticle fragments. Leaves are awl-shaped, keeled, entire-margined, up to $1.5 \mathrm{~mm}$ long with a maximum width of $1 \mathrm{~mm}$ (Fig. 3A, C). Leaves are unequally amphistomatic. Stomatal complexes are cyclocytic, with 4-6 subsidiary cells. Stomatal apertures are randomly oriented with respect to the leaf axis, and are strongly protected by papillae (Fig. 4A, B, D, H, J-M). Rectangular epidermal cells are oriented longitudinally and average $58 \mu \mathrm{m}$ long by $20 \mu \mathrm{m}$ wide (Fig. 4B, C, E, G). Epidermal cells are non-papillate or slightly inflated (Fig. 4I), as opposed to slightly papillate as described by Cantrill and Douglas (1988).

Comments: Leaves recovered in this study are smaller than those recorded from the Otway Basin by Cantrill and Douglas (1988) or the Eromanga Basin by Pole (2000). Material originally assigned to this species by Cantrill and Douglas (1988) was derived from the Racecourse Steps and Devils Kitchen localities (Otway Basin), but identical leaves and cuticle fragments were recorded from several additional Albian localities in this study. Cantrill and Douglas (1988) originally suggested a taxodiaceous (= cupressaceous) affinity for these remains, based on comparison of dimorphic foliage, leaf shape and stomatal features with extant taxa. Stomatal bands with papillate epidermal cells occur in some other conifer families (e.g., Cupressaceae (Taxodiaceae)Elatides (Harris, 1979); Podocarpaceae/Cupressaceae-Bellarinea richardsii; Nagalingum et al., 2005), leading Cantrill and Douglas (1988) to place these leaves in Geinitzia (a genus recently reassigned
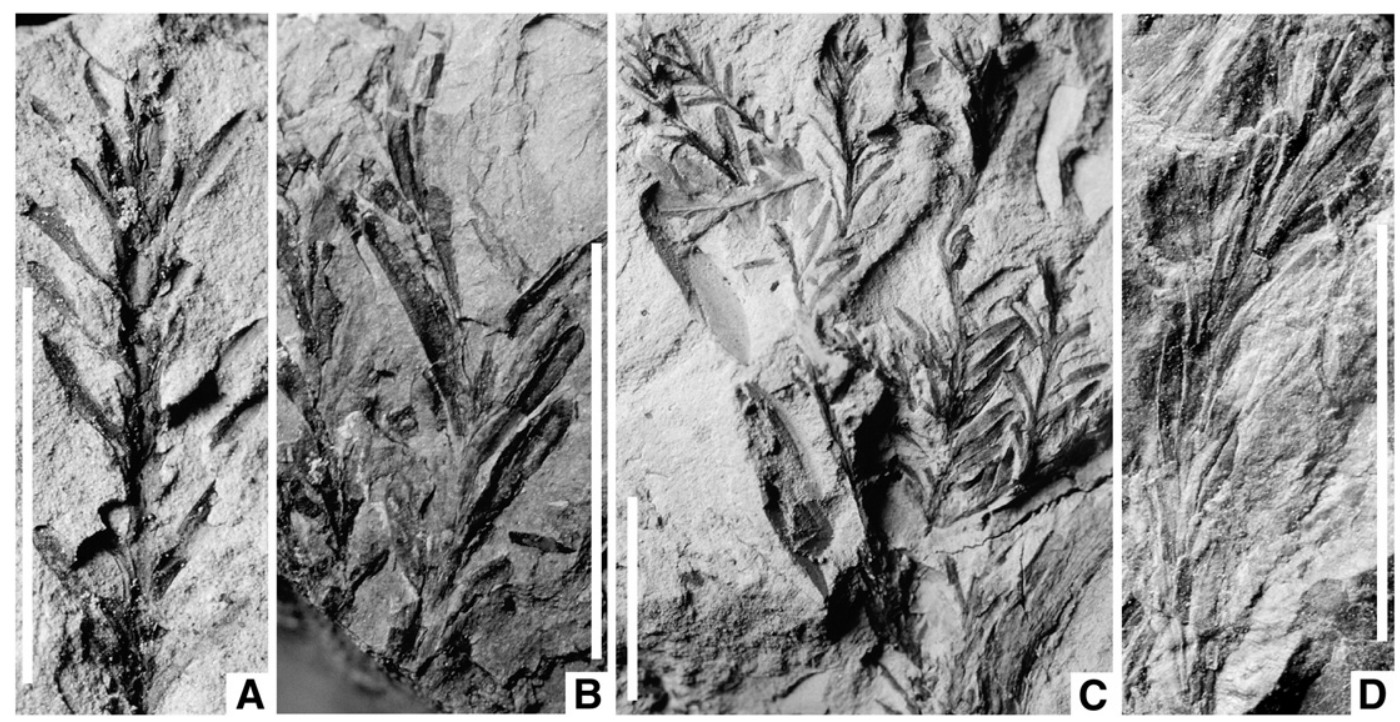

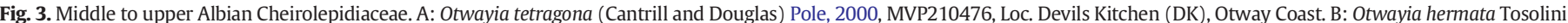

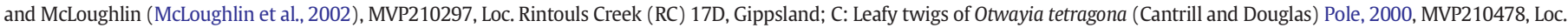

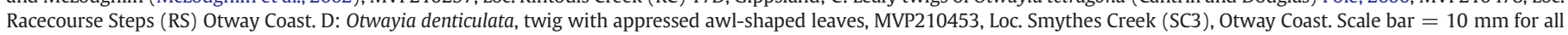
specimens. 

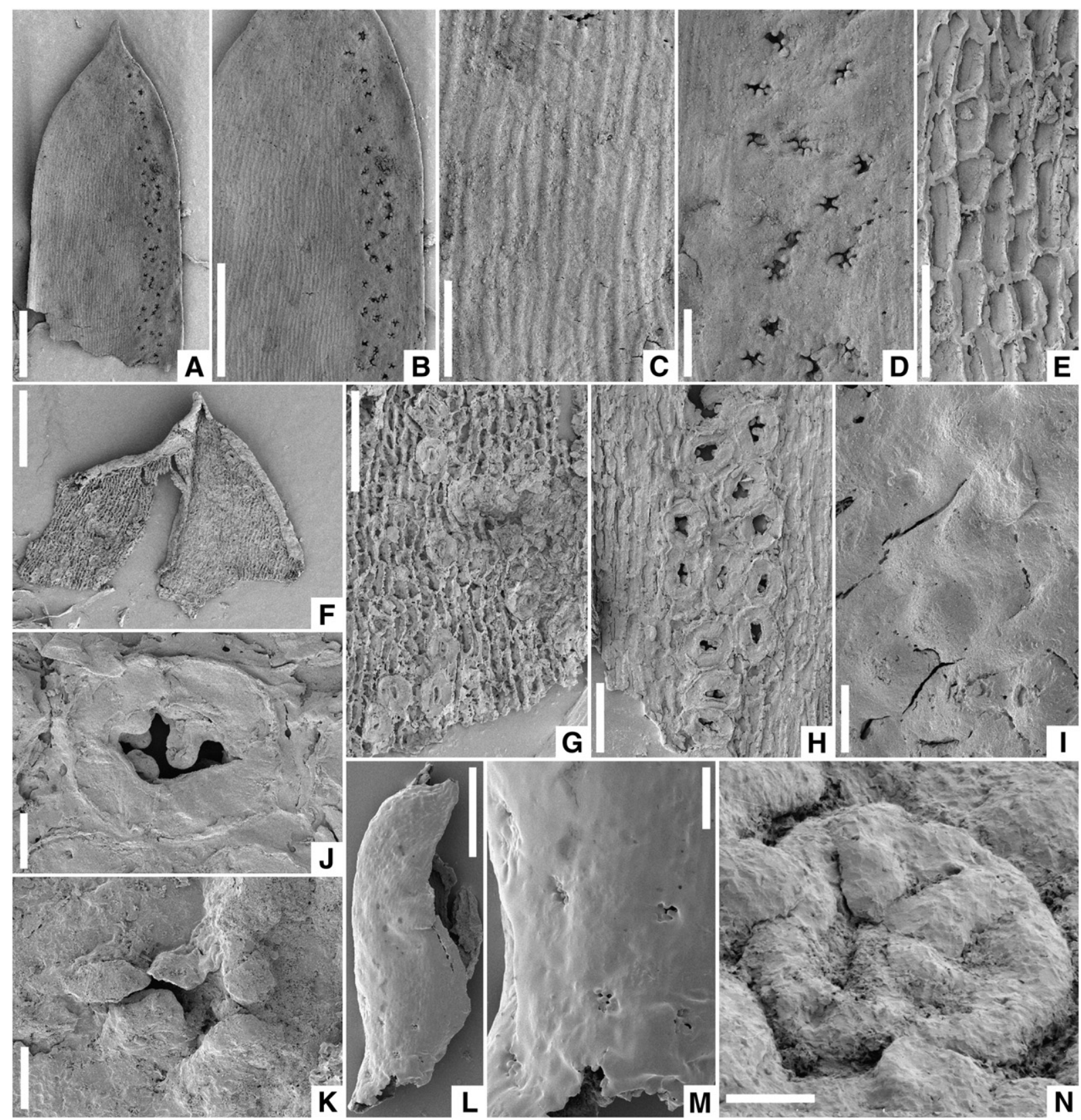

D

E
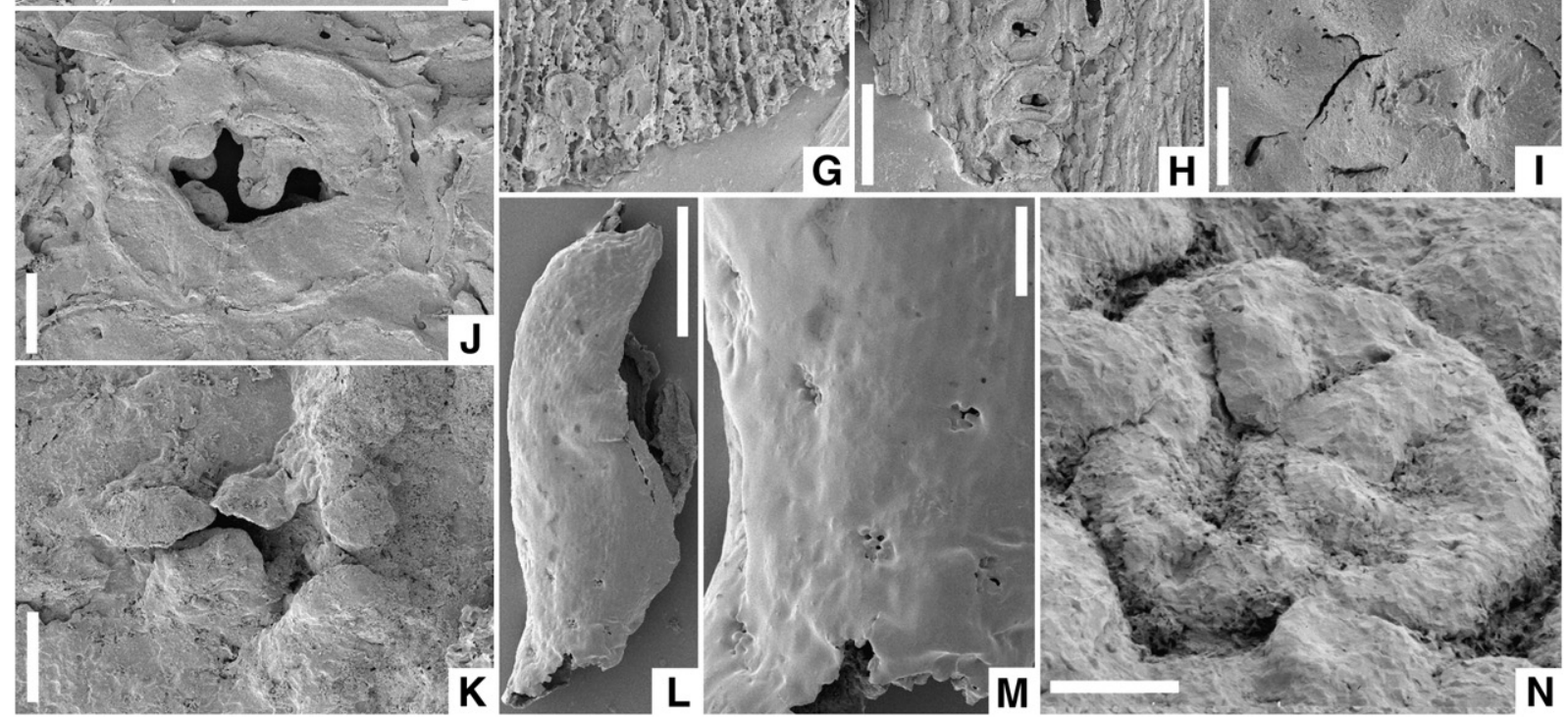

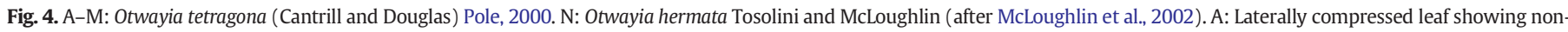

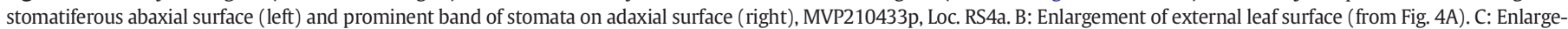

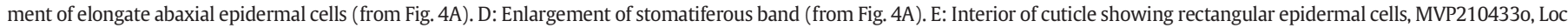

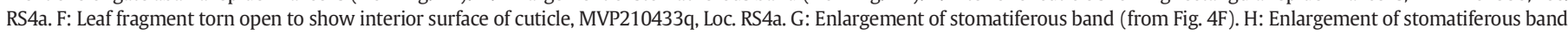

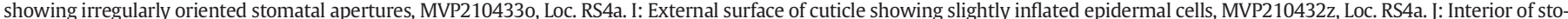

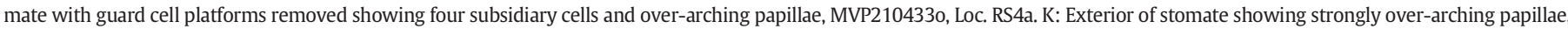

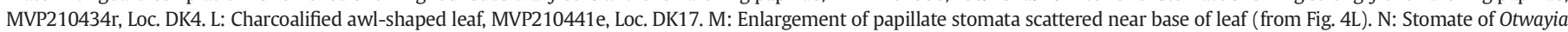

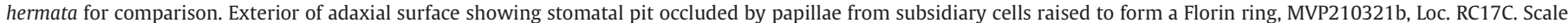
bar $=500 \mu \mathrm{m}$ for A, B, F, L; $200 \mu \mathrm{m}$ for G; $100 \mu \mathrm{m}$ for C-E, H, M; $20 \mu \mathrm{m}$ for I, J; $10 \mu \mathrm{m}$ for K, N.

to an extinct conifer family Geinitziaceae; Kunzmann, 2010). The species was reassigned to Otwayia by Pole (2000), who described additional material from mid-Cretaceous strata of the Eromanga Basin, northeastern Australia. He considered the genus to have cheirolepidiacean affinities based on his "Cheirolepidiaceae placement rule 1" whereby "if subsidiary cells or encircling cells are papillate and subsidiary or encircling cell papillae project laterally across stomatal pore, then family is Cheirolepidiaceae" (Pole, 2000, p. 197). Further, leaf dimorphism occurs in the Cheirolepidiaceae (e.g. Tomaxellia biforme) of South America (Archangelsky, 1968). The unique combination of small and commonly appressed awl-shaped leaves, cyclocytic stomatal complexes borne mostly on the adaxial surface in bands, strongly sunken stomata with overarching papillae, and association with Classopollis in the sediments, reinforces the assignment to Cheirolepidiaceae.

Distribution: O. tetragona occurs in Aptian to Albian strata of the Eumeralla Formation in the Otway Basin. It is a common to abundant component of mesofossil assemblages from: Castle Cove sites CC1h, CC2a, CC2d, CC30, CC32, CC33, and CC35; Moonlight Head site MHr; Racecourse Steps sites ?RS2p, RS2y, and RS2ci; and Devils Kitchen sites DK2, DK4, DK7b and DK7c (Fig. 1). The only other records of this species are from the Albian-Cenomanian Mackunda and Winton 
formations of the Eromanga Basin in northeastern Australia, although those specimens differ slightly in having less regularly oriented stomata that are not in clear rows on the adaxial surface (Pole, 2000).

Otwayia hermata Tosolini and McLoughlin (in McLoughlin et al., 2002) (Fig. 4N)

Material examined: Fifteen specimens examined (see McLoughlin et al., 2002). Museum Victoria specimen numbers: macrofossils MVP210295-MVP210298; mesofossils on SEM stubs MVP210292, MVP210318-MVP210322, MVP210371-MVP210372, inclusive.

Diagnosis and type details: Provided by McLoughlin et al. (2002); the main characters are summarized here in Table 1 for comparative purposes.

Comments: McLoughlin et al. (2002) described the details of this Hauterivian-Barremian species from the Tyers Subgroup, Gippsland Basin. No additional samples have been found from younger sediments of the Gippsland or Otway basins. The cuticular features, such as strongly elongate apical cells of leaves, robust papillation of regular epidermal cells, randomly oriented stomatal apertures, a Florin ring incorporating 4-6 strongly papillate subsidiary cells overarching the sunken stomata in a cyclocytic arrangement (Fig. $4 \mathrm{~N}$ ), suggest that this species is a member of the Cheirolepidiaceae (Watson, 1988; Pole, 2000). Spirally arranged, small, awl-shaped leaves with thick cuticle and stomata arranged in bands are typical of the non-frenelopsid cheirolepids (Watson, 1988; del Fueyo et al., 2008). No fertile material is associated with these leaves. Classopollis pollen is co-preserved in the sediments (Dettmann, 1963; this study), evidence that the representatives of Cheirolepidiaceae are present in the riparian vegetation. No other leaf fossils from these strata have features characteristic of this family

Otwayia hermata differs from Otwayia tetragona (Cantrill and Douglas) Pole, 2000 by its shorter and broader papillae on subsidiary cells. It is also somewhat similar in features, such as leaf shape, stomatal orientation, strongly sunken stomata and heavily papillated subsidiary cells raised to form a Florin ring, to Pagiophyllum currii Harris (1979) from the Yorkshire Jurassic and Pseudofrenelopsis parceramosa (Fontaine) Watson, 1974 (see Table 1) from the English Wealden (Watson, 1977; Alvin, 1982). However, more prominent papillae on the abaxial surface and the fringe of elongate apical cells, distinguish the Victorian species. The foliar variation from basally appressed and imbricate on a branch to apically spreading, has similarities to, but is less pronounced than in Tomaxellia Archangelsky, 1963, which has distinct heterophylly, a character not recognized in other South American Early Cretaceous conifers (Kunzmann et al., 2006).

Distribution: Recorded from numerous Valanginian-Hauterivian assemblages in the Boola Boola Forest area (see Appendix I, p. 40 and Fig. 5 in McLoughlin et al., 2002); Tyers River Subgroup; Gippsland Basin.

Otwayia denticulata Tosolini sp. nov. (Figs. 3D, 5A-M)

Holotype: MVP210406c (Museum Victoria).

Material examined: Nine specimens examined (all apart from the holotype are paratypes: see Tosolini, 2001). Museum Victoria specimen numbers: macrofossil MVP210453; mesofossils on SEM stubs MVP210390-MVP210397, inclusive.

Type locality, formation and age: Moonlight Head (1j), Eumeralla Formation, Otway Group; Albian.

Etymology: Named after the denticulate margin and fringe on the acuminate apex that distinguishes this species from other entiremargined Otwayia species.

Diagnosis: Leaves triangular or ovate (awl-like or claw-like); prominently keeled on the abaxial surface. Leaf margin denticulate or entire with a denticulate fringe on the acuminate apex. Leaves epistomatic. Epidermal cells inflated but lacking distinct papillae. Stomata arranged in two bands in an inverted V-shaped array. Stomata strongly sunken and protected by up to seven overarching papillae.

Description: Only a single macrofossil and rare dispersed leaves are available; the shoot phyllotaxy is spiral. The awl-like or claw-like leaves reach $3 \mathrm{~mm}$ long and $1.2 \mathrm{~mm}$ wide at the base (Fig. 5A, C-E, G, I). They have an acuminate tip and typically a denticulate margin formed by extended epidermal cells (Fig. 5E, G, H). The basal attachment is broad (i.e., the leaf base is typically expanded with a broad scar) and slightly decurrent. Epidermal cells are inflated but lack distinct papillae. They are rectangular on the abaxial side but square on the adaxial side, particularly near the apex. Venation is unclear but the presence of a prominent abaxial keel suggests a single midvein and this is supported by the presence of a single stomata-free band along the centre of the leaf. Leaves are epistomatic, hence stomata were further protected by foliar imbrication. We refer readers to the figure of the macrofossil, which shows this imbrication (Fig. 3D). Stomata are arranged in two bands approximately $100 \mu \mathrm{m}$ from the margins and extending from the base almost to the apex of the leaf in an inverted V-shaped array. One to two stomata form rows within the bands. Stomatal orientation appears random and pore shape is slit-like as it is obscured by overarching papillae. Strongly sunken stomata are protected by up to seven over-arching, robust, short, broad, blunt, and rounded papillae on 4 to 7 subsidiary cells (Fig. 5B, F, J, K).

Comments: Otwayia denticulata is very similar to 0 . tetragona (Table 1 ) but the former has leaves with distinct marginal denticles, expanded bases, cuticle that is epistomatic, less stomata per stomatal zone (1-2 rather than 2-5), lack of a Florin ring, shorter and broader, blunt papillae on the subsidiary cells and have more inflated, rectangular epidermal cells. The close similarity to 0 . tetragona, and especially its diminutive, awl-shaped, acuminate leaves, with heavily papillate protection of sunken stomata, suggests that 0 . denticulata is also a cheirolepidiacean conifer (Watson, 1988; Pole, 2000).

Similarities also exist between $O$. denticulata and 0 . hermata, from the Valanginian-Barremian of the Gippsland Basin, southeastern Australia (Table 1). Characters that differ include a triangular or ovate leaf shape, a denticulate margin and apex, an acuminate tip, random stomatal distribution that is epistomatic, lack of a Florin ring and lack of papillae on epidermal cells. Otwayia denticulata can be distinguished from Otwayia cudgeloides described from the Cenomanian of the Eromanga Basin, northern Australia, by its awl-like leaves with a prominent keel, denticulate margin, varied number of subsidiary cells (4-7) with short, broad, rounded papillae, and inflated, rectangular to square epidermal cells, compared to the long papillae on subsidiary cells and sharp conate papillae on epidermal cells in O. cudgeloides (Pole, 2000).

Distribution: This species is restricted to Aptian and Albian strata of the Otway Basin, with a distribution similar to that of $O$. tetragona, although markedly less abundant. $O$. denticulata was recorded from the following sites: Smythes Creek, SC3; Castle Cove, CC2l; Moonlight Head, MHj, MHk; Racecourse Steps, RS4a; and Devils Kitchen, DK2 (Fig. 1).

Cheirolepidiaceae cuticle sp. A (Fig. 6A-G)

Material examined: Two specimens examined (see Tosolini, 2001). Museum Victoria specimen number: mesofossils on SEM stub MVP210435, letters n, o.

Description: This form is represented only by cuticle fragments up to $500 \mu \mathrm{m}$ long and $300 \mu \mathrm{m}$ wide. The cuticle bears distinct, broad, stomatiferous bands and intervening non-stomatiferous bands (Fig. 6A, E, F). All epidermal cells are strongly inflated and within stomatal bands they are irregularly polygonal with straight or slightly beaded walls (Fig. 6A, C, F). However, within inter-stomatal bands the epidermal cells are elongate-rectangular, with thick, strongly buttressed walls, giving a highly sinuous appearance (Fig. 6D). Stomatal complexes are cyclocytic, measuring $50 \mu \mathrm{m}$ in diameter; they occur scattered within the stomatiferous bands, are sunken, and their apertures are irregularly oriented (the majority appear oblique or perpendicular to the leaf axis). The stomatal pits are heavily protected and obscured by four or five (rarely six) over-arching, blunt, papillae (Fig. 6B, G). A Florin ring is not developed.

Comments: The papillate protection of the stomata and strongly inflated epidermal cells suggest cheirolepidiacean affinities but further details are lacking to provide confident generic assignment. Although 
Table 1

Comparison between Australasian species of Cheirolepidiaceae based on cuticular morphology; all are of Cretaceous age (after Cantrill and Douglas, 1988; Pole, 2000; McLoughlin et al., 2002; Pole and Philippe, 2010; this paper.).

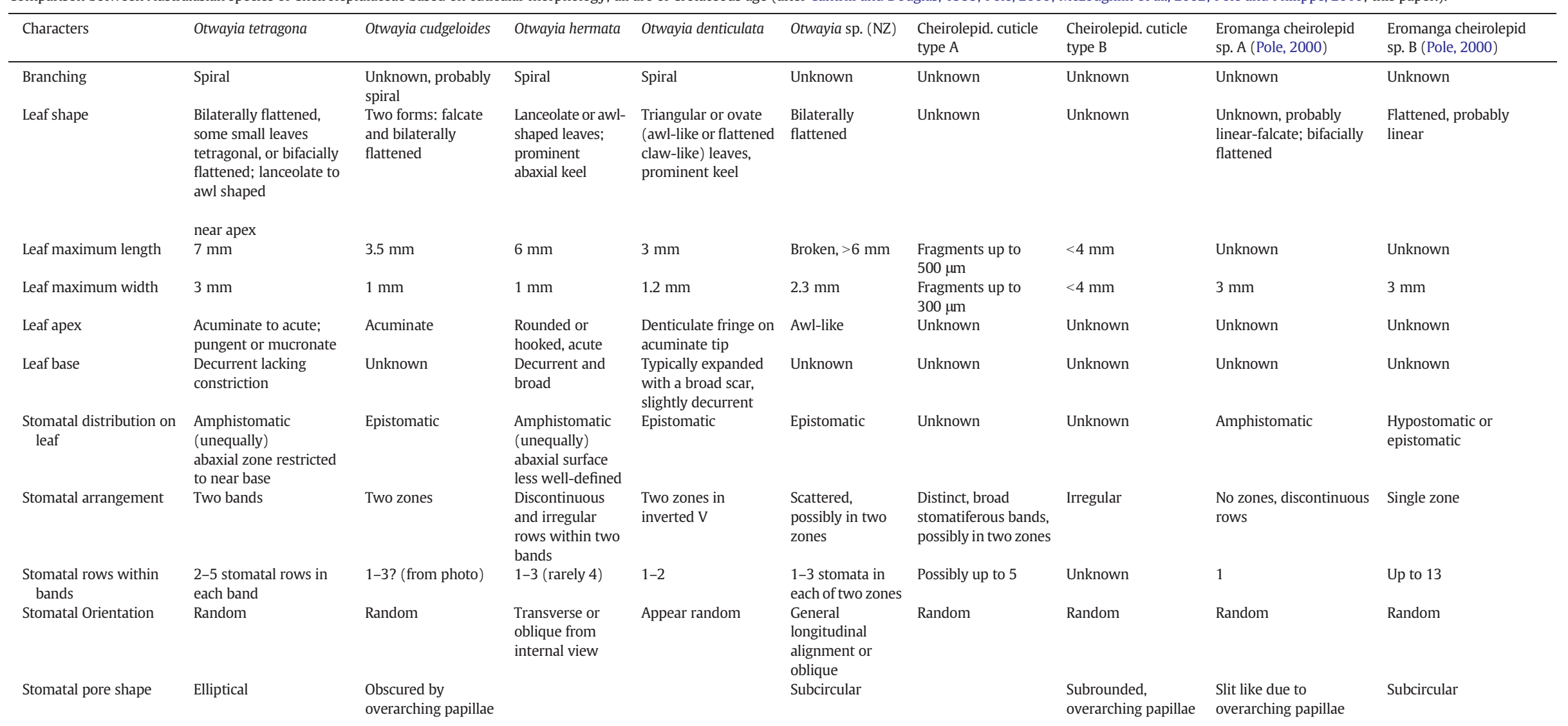




\begin{tabular}{|c|c|c|c|c|c|c|c|c|c|}
\hline & & & $\begin{array}{l}\text { Obscured by } \\
\text { overarching } \\
\text { papillae }\end{array}$ & $\begin{array}{l}\text { Slit-like as obscured } \\
\text { by overarching } \\
\text { papillae }\end{array}$ & & $\begin{array}{l}\text { Slit like internally } \\
\text { and externally due to } \\
\text { overarching papillae }\end{array}$ & & & \\
\hline $\begin{array}{l}\text { Subsidiary cell number, } \\
\text { arrangement }\end{array}$ & $\begin{array}{l}\text { Dicyclic, encyclocytic, } \\
4-6 \text { subsidiary cells }\end{array}$ & $5 ?$ & $\begin{array}{l}\text { Cyclocytic, 4-6 } \\
\text { subsidiary cells }\end{array}$ & $4-7$ & $\begin{array}{l}\text { 4-5? (from } \\
\text { photo) }\end{array}$ & $4-5$ & Encyclocytic; 4-6 & Dicyclic, encyclocytic, & $\begin{array}{l}\text { Dicyclic, encyclocytic, } \\
\text { typically } 4-5 \text { subsidiary } \\
\text { cells }\end{array}$ \\
\hline Florin ring & $\begin{array}{l}\text { Present? Cuticle thicker } \\
\text { over subsidiary cells } \\
\text { than over other cells } \\
\text { (Pole, 2000) }\end{array}$ & Absent or degraded & $\begin{array}{l}\text { Present, } 5 \mu \mathrm{m} \\
\text { high }\end{array}$ & Absent? & $\begin{array}{l}\text { Massively } \\
\text { thickened rims }\end{array}$ & Absent? & Absent & Absent & Absent? (from photo) \\
\hline Subsidiary cell papillae & $\begin{array}{l}\text { Elongate, narrow and } \\
\text { tapered, almost } \\
\text { completely covering } \\
\text { stomatal pore }\end{array}$ & Long & $\begin{array}{l}\text { Short, broad and } \\
\text { blunt, up to } \\
11 \mu \mathrm{m} \text { long cover } \\
\text { the stomatal pit. }\end{array}$ & $\begin{array}{l}\text { Short, broad and } \\
\text { blunt, circular in } \\
\text { section, up to } 10 \mu \mathrm{m} \\
\text { long cover the } \\
\text { stomatal pit. }\end{array}$ & $\begin{array}{l}\text { Partially fused at } \\
\text { base, very short, } \\
\text { not extending } \\
\text { over stomatal } \\
\text { pore }\end{array}$ & $\begin{array}{l}\text { Long, broad and } \\
\text { blunt, circular in } \\
\text { section, up to } 20 \mu \mathrm{m} \\
\text { long }\end{array}$ & $\begin{array}{l}\text { Outer papillae are } \\
\text { long, flattened, up to } \\
45 \mu \mathrm{m} \text { long }\end{array}$ & $\begin{array}{l}\text { Massive papillae across } \\
\text { pore from encircling } \\
\text { cells }\end{array}$ & $\begin{array}{l}\text { Two per subsidiary, } \\
\text { circular in section, broad } \\
\text { and low, unconnected }\end{array}$ \\
\hline $\begin{array}{l}\text { Papillae in stomatal } \\
\text { crypt }\end{array}$ & No & No & No & No & No & No & $\begin{array}{l}\text { Flattened, reaching } \\
20 \mu \mathrm{m} \text { long in throat } \\
\text { of stomatal crypt }\end{array}$ & No & No \\
\hline Guard cells & $\begin{array}{l}\text { Sunken with polar } \\
\text { extensions; orientated } \\
\text { longitudinally or slightly } \\
\text { obliquely }\end{array}$ & $\begin{array}{l}\text { Sunken? (from } \\
\text { photo) }\end{array}$ & $\begin{array}{l}\text { Sunken within a } \\
\text { stomatal pit }\end{array}$ & Strongly sunken & $35-40 \mu \mathrm{m}$ & Strongly sunken & Strongly sunken & Sunken? (from photo) & Sunken? (from photo) \\
\hline $\begin{array}{l}\text { Epidermal cell size and } \\
\text { shape }\end{array}$ & $\begin{array}{l}\text { Square to rectangular; } \\
15-25 \mu \mathrm{m} \text { wide by } \\
40-90 \mu \mathrm{m} \text { long }\end{array}$ & $\begin{array}{l}\text { Polygonal, more or } \\
\text { less isodiametric }\end{array}$ & $\begin{array}{l}\text { Equidimensional, } \\
\text { squat-shaped, } \\
35 \mu \mathrm{m} \text { in } \\
\text { diameter }\end{array}$ & $\begin{array}{l}\text { Rectangular on } \\
\text { abaxial side, square } \\
\text { on adaxial side } \\
\text { particularly near } \\
\text { apex }\end{array}$ & $\begin{array}{l}\text { Elongate, } \\
\text { rectangular }\end{array}$ & $\begin{array}{l}\text { Irregularly polygonal } \\
\text { within stomatal } \\
\text { bands, elongate, } \\
\text { rectangular } \\
\text { elsewhere }\end{array}$ & $\begin{array}{l}\text { Polygonal but } \\
\text { indistinct }\end{array}$ & $\begin{array}{l}\text { Isodiametric, polygonal, } \\
\mathrm{L} / \mathrm{W}<2.0 \text { (maximum } \\
3.4 \text { ); flanges smooth, }\end{array}$ & $\begin{array}{l}\text { Elongate, rectangular on } \\
\text { adaxial surface, abaxial } \\
\text { surface more polygonal }\end{array}$ \\
\hline Epidermal cell papillae & $\begin{array}{l}\text { Non-papillate to slightly } \\
\text { papillate }\end{array}$ & $\begin{array}{l}\text { Sharp, conate } \\
\text { papillae }\end{array}$ & $\begin{array}{l}\text { Papillate (up to } \\
5 \mu \mathrm{m} \text { high) on } \\
\text { adaxial side, less } \\
\text { papillate to } \\
\text { smooth on } \\
\text { abaxial side }\end{array}$ & $\begin{array}{l}\text { Inflated, but no } \\
\text { distinct papillae }\end{array}$ & Nonpapillate & Strongly inflated & Glabrous & Glabrous & Glabrous \\
\hline Epidermal cell walls & $\begin{array}{l}\text { Beaded thickenings, } \\
\text { (slightly sinuous), } \\
\text { straight, unbuttressed }\end{array}$ & $\begin{array}{l}\text { Straight, } \\
\text { unbuttressed }\end{array}$ & $\begin{array}{l}\text { Straight, } \\
\text { unbuttressed }\end{array}$ & $\begin{array}{l}\text { Straight, } \\
\text { unbuttressed }\end{array}$ & $\begin{array}{l}\text { Straight, blunt } \\
\text { endwalls }\end{array}$ & $\begin{array}{l}\text { Straight or slightly } \\
\text { beaded in stomatal } \\
\text { bands, unbuttressed }\end{array}$ & $\begin{array}{l}\text { Beaded thickenings, } \\
\text { (slightly sinuous), } \\
\text { unbuttressed }\end{array}$ & Straight, unbuttressed & Straight, unbuttressed \\
\hline Associated organs & $\begin{array}{l}\text { Slender axes and } \\
\text { mycorrhizal roots }\end{array}$ & None & Slender axes & Slender axes & None & None & None & None & None \\
\hline Occurrence (formations) & $\begin{array}{l}\text { Eumerella Formation, } \\
\text { Otway Group; Allaru, } \\
\text { Mackunda and Winton } \\
\text { formations }\end{array}$ & $\begin{array}{l}\text { Allaru, Mackunda } \\
\text { and Winton } \\
\text { formations }\end{array}$ & $\begin{array}{l}\text { Rintouls Creek } \\
\text { Formation, Tyers } \\
\text { River Subgroup, } \\
\text { Strzelecki Group }\end{array}$ & $\begin{array}{l}\text { Eumerella } \\
\text { Formation, Otway } \\
\text { Group }\end{array}$ & $\begin{array}{l}\text { Tupuangi } \\
\text { Formation }\end{array}$ & $\begin{array}{l}\text { Eumerella } \\
\text { Formation, Otway } \\
\text { Group }\end{array}$ & $\begin{array}{l}\text { Eumerella } \\
\text { Formation, Otway } \\
\text { Group }\end{array}$ & $\begin{array}{l}\text { Allaru, Mackunda and } \\
\text { Winton formations }\end{array}$ & $\begin{array}{l}\text { Allaru, Mackunda and } \\
\text { Winton formations }\end{array}$ \\
\hline Age range & Aptian-Albian & Albian-Cenomanian & Neocomian & Aptian-Albian & $\begin{array}{l}\text { Albian- } \\
\text { Santonian }\end{array}$ & Aptian-Albian & Aptian-Albian & Albian-Cenomanian & Albian-Cenomanian \\
\hline
\end{tabular}



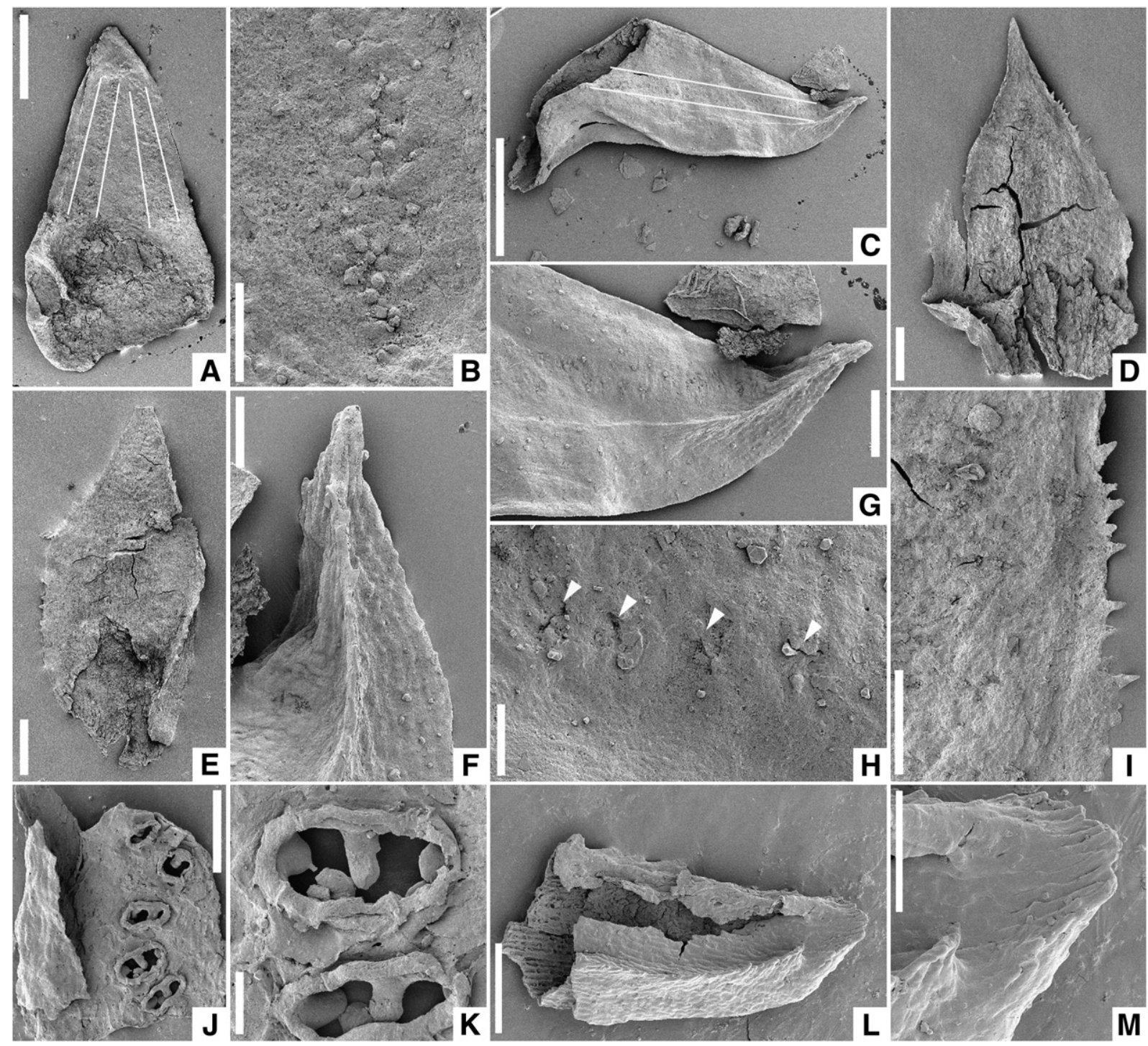

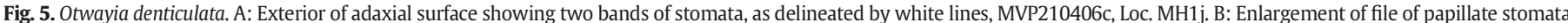

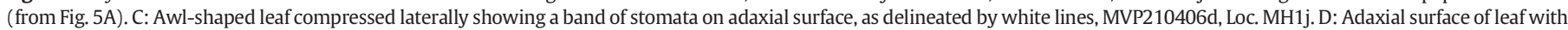

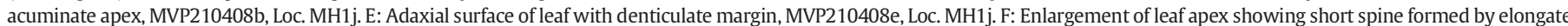

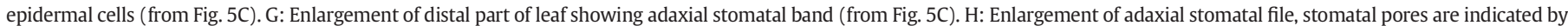

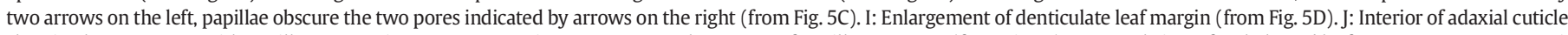

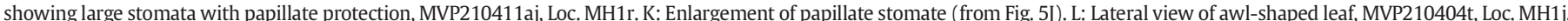

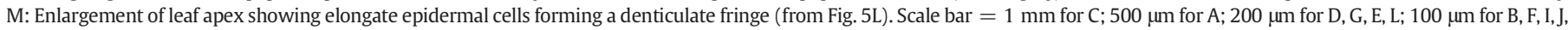
M; $50 \mu \mathrm{m}$ for $\mathrm{H} ; 20 \mu \mathrm{m}$ for $\mathrm{K}$.

some other conifer families have weakly developed papillae on subsidiary cells (e.g., some podocarps such as Smithtonia and Willungia have raised stomatal rims that may be divided into irregular lobes; Hill and Pole, 1992), Cheirolepidiaceae are noted for their strongly overarching papillae that essentially block the stomatal pore (Pole, 2000). Despite lacking complete leaves, the heavily papillate stomatal protection of Cheirolepidiaceae cuticle sp. A is similar to that of Otwayia species. $O$. hermata differs by its stomatal subsidiary cells being raised above the epidermal cells to form a Florin ring. O. tetragona has shorter papillae over the stomata, so that they do not completely block the pore, and the epidermal cells are not inflated but rather are non-papillate to slightly papillate. $O$. cudgeloides differs by having very long and sharp papillae on epidermal cells. Eromanga cheirolepid sp. A and sp. B of Pole (2000) both differ in having non-papillate epidermal cells and stomata in rows rather than bands. Similar to Cheirolepidiaceae cuticle sp. A, inflated epidermal cells known as "cobblestones" characterize
Frenelopsis harrisii Doludenko and Reymanowna, 1978, though two ranks of papillae occur in the stomata of the latter. Androvettia (Hueber and Watson, 1988), a probable cheirolepid, has stomata with much larger papillae overhanging the pit (Watson, 1988).

Several of the key characters of this taxon occur in other conifer families but the combination of traits is unique. For example, Bellarinea richardsii, of probable podocarpacean affinity from the Early Cretaceous of the Gippsland Basin (Nagalingum et al., 2005), has weakly developed papillae surrounding the stomate, but not blocking the opening. Some Cupressaceae species have similar characters: inflated epidermal cells (e.g. Xanthocyparis vietnamensis; Xiang and Farjon, 2003), and papillae surrounding, but not overarching the stomatal complex, occur in both fossil and extant Metasequoia glyptostroboides (Leng et al., 2001) from China. Fossils Libocedrus acutifolius and Libocedrus obtusifolius from the late Paleocene of Australia (Whang and Hill, 1999) have a Florin ring that is divided into lobes, but no true papillae overarching the stomatal 


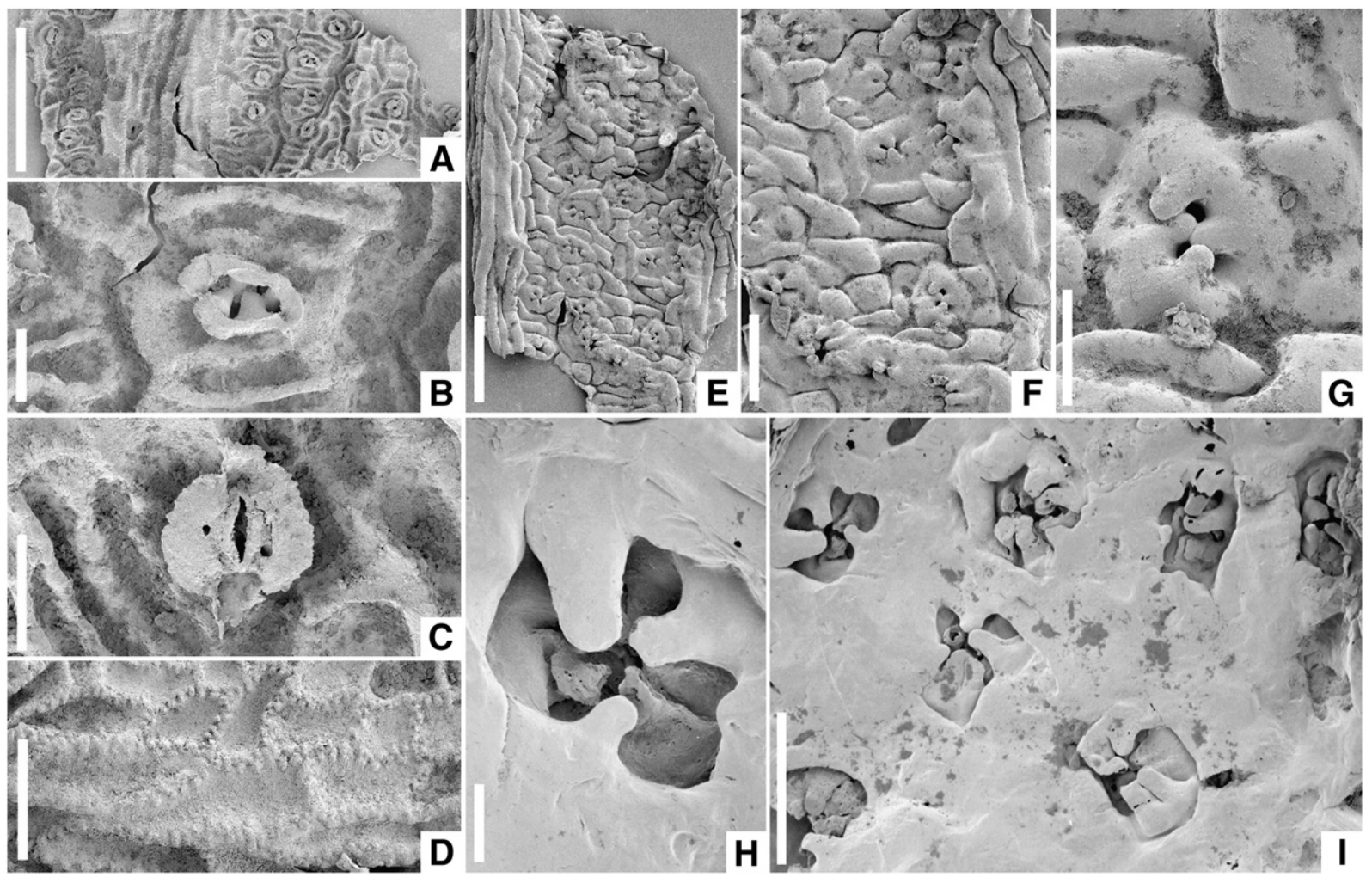

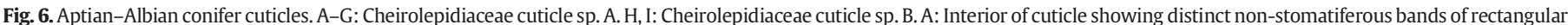

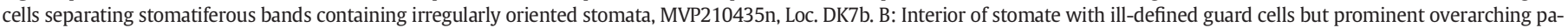

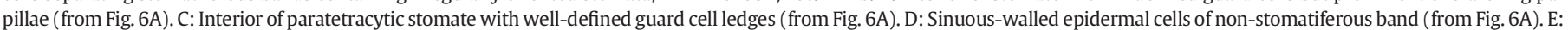

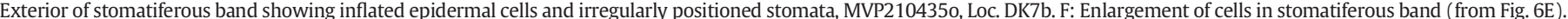

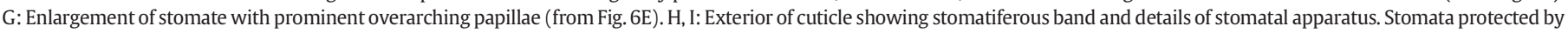
two ranks of papillae, MVP210378e, Loc. ENG7. Scale bar $=200 \mu \mathrm{m}$ for A; $100 \mu \mathrm{m}$ for E, I; $50 \mu \mathrm{m}$ for F, D; $20 \mu \mathrm{m}$ for B, C, G, H.

pore. Pseudotorellia linkii Watson in Watson and Harrison, (1998), has overarching papillae on subsidiary cells but is distinctly multiveined (Watson and Harrison, 1998).

Distribution: Recorded only from bulk maceration of sediment from the Eumeralla Formation (Albian) at locality DK7b (Fig. 1).

Cheirolepidiaceae cuticle sp. B (Fig. 6H, I)

Material examined: One specimen examined (see Tosolini, 2001). Museum Victoria specimen number: mesofossil on SEM stub MVP210378, letter e.

Description: This form is represented only by cuticle fragments a few millimetres in diameter, $<4 \mathrm{~mm}$ long and $<3 \mathrm{~mm}$ wide. Epidermal cells on these cuticle fragments appear to have smooth periclinal walls, although preservation has flattened and damaged the cuticle. Irregularly distributed and oriented stomata occur in deeply sunken pits and are protected by papillae in two ranks (derived from two cycles of subsidiary cells: Fig. $6 \mathrm{H}, \mathrm{I}$ ). Each rank has four to six papillae (4-6 cells per ring). The outer papillae are up to $45 \mu \mathrm{m}$ long, whereas inner papillae (present in the throat of the stomatal crypt) reach only $20 \mu \mathrm{m}$ long. The whole stomatal complex is $80 \mu \mathrm{m}$ in diameter.

Comments: Since shoot phyllotaxy and leaf shape are not known, the affinities of these fragmentary cuticles cannot be definitively ascertained. However, the sunken stomata protected by two ranks of papillae strongly favours cheirolepidiacean affinities (Watson, 1988). Similar deeply sunken stomata protected by a double ring of papillae occur on some Northern Hemisphere Cheirolepidiaceae leaves (Gomez et al., 2002b), such as: Frenelopsis, e.g., Frenelopsis alata (Feistmantel) Knobloch, 1971 (Alvin, 1977; Kvaček, 2000) from the Cretaceous of Europe and U.S.A.; Frenelopsis harrisii Doludenko and Reymanowna, 1978 from the Cretaceous of Tajikistan (Watson, 1988); and Frenelopsis hoheneggeri (Ettingshausen) Schenk emend. Reymanówna and Watson,
1976, from the Cretaceous of Poland and the Czech Republic (Gomez et al., 2002b). Frenelopsis commonly has non-papillate Florin rings, but inner papillae protrude within the stomatal pit (Gomez et al., 2002b), except for Frenelopsis ramosissima (Watson, 1977; Upchurch and Doyle, 1981), which, like Pseudofrenelopsis, possesses overarching external papillae projecting from a Florin ring (Srinivasan, 1995) and no inner papillae. The Gippsland specimens are, therefore, more like Frenelopsis (Watson, 1988; Gomez et al., 2002b). Gondwanan examples of Frenelopsis are known from the Crato Formation of Brazil, South America, but those specimens are too poorly preserved to yield anatomical details within the stomata and the Florin ring is non-papillate (Kunzmann et al., 2006).

Distribution: This cuticle type was recorded only from the Gippsland Basin Eagles Nest locality within Aptian sediments of the "Wonthaggi formation', Strzelecki Group (sites ENG1 and ENG7; Fig. 1).

\subsection{Cheirolepidiacean pollen}

The distinctive spherical pollen with a circular germinal furrow attributed to Cheirolepidiaceae has been generally assigned to Classopollis or Corollina in Australian Mesozoic palynological studies. Relatively few species of this pollen group have been distinguished as separate formal species in these studies. As stated by Reyre (1970), the assignment of a dispersed Classopollis grain to a definite species is always difficult and often impossible. Australian Cretaceous palynological studies have generally recognized only four species. Dettmann (1963) referred to pollen from the Early Cretaceous in southeast Australia as Classopollis cf. Classopollis classoides Pflug, 1953, whereas in northeastern Australia Burger (1980) referred to similar grains as Classopollis cf. Classopollis chateaunovi Reyre, 1970. In younger sediments from Bathurst Island, 
Burger (in Norvick and Burger, 1975) also recorded Classopollis simplex (Danzé-Corsin and Laveine, 1963) Reiser and Williams, 1969 and illustrated an undescribed species. Most Australian consultancy reports (e.g. Harms and Bennell, 1999) have regularly recognized the species Classopollis torosus (Reissinger, 1950) Couper, 1958 emend. Burger, 1965. In this study, the four species of Classopollis recorded, one of which is probably reworked, are outlined below based on transmitted light microscopy. Materials examined are from palynological slides with Museum Victoria registration numbers MVP23599-MVP236059 inclusive.

Genus Classopollis (Pflug, 1953) Srivastava, 1976

Type species: Classopollis classoides Pflug, 1953 (original designation)

Classopollis chateaunovi Reyre, 1970 (Fig. 7C-E)

Synonymy: For full synonymy see Raine et al. (2011).

Description: Grains anisopolar, amb circular to oval, appearing to be originally spherical or ovoid, but often compressed in a polar direction. Exine 1-1.5 $\mu \mathrm{m}$, thicker in the equatorial region and thinning towards the poles, with a sculpture of regularly distributed, small $(<0.5 \mu \mathrm{m})$, isolated, but more often coalesced, verrucae that form an incomplete pseudoreticulum. Sculpture in the equatorial region is aligned in rows to form heavily disrupted pseudostriations. The average overall width of the equatorial band is $8 \mu \mathrm{m}$. Rimula is not observed. Proximal pole occasionally has a triangular area (sides of triangle up to $6 \mu \mathrm{m}$ ) in which the exine is absent. Distal pole is characterized by the presence of a circular pore $5-12.5 \mu \mathrm{m}$ in diameter.
Grain size: Equatorial diameter 30(38)45 $\mu \mathrm{m}$ (20 specimens measured).

Comments: The New Zealand fossil pollen and spore catalogue (Raine et al., 2011) retains the species Classopollis chateaunovi and tentatively also includes both $C$. classoides and $C$. torosus in this species. The current study rejects the inclusion of the latter two taxa based on the verrucate sculpture that forms an incomplete pseudoreticulum and the pseudostriations on the equatorial band and retains $C$. chateaunovi as a distinct species. One morphological type of Classopollis recorded from Valanginian to Albian strata of the Gippsland and Otway basins in this study is placed in C. chateaunovi (Fig. 7C-E). Reyre (1970) distinguished this species as having only vague pseudostriations and a grumous-verrucose sculpture. Specimens in this study that have this coarser type of sculpture and a very disrupted equatorial band created by aligned, commonly coalesced veruccae are placed in C. chateaunovi (Fig. 7C-E). The specimens of $C$. chateaunovi in this study are in general larger than those recorded by Reyre (1970).

Distribution: In this study, C. chateaunovi is recorded from Paradise Creek and Eagles Nest in the Gippsland Basin (Valanginian-Aptian) and Devils Kitchen, Racecourse Steps and Moonlight Head in the Otway Basin (Albian).

Classopollis simplex (Danzé-Corsin and Laveine, 1963) Reiser and Williams, 1969 (Fig. 7A-B)
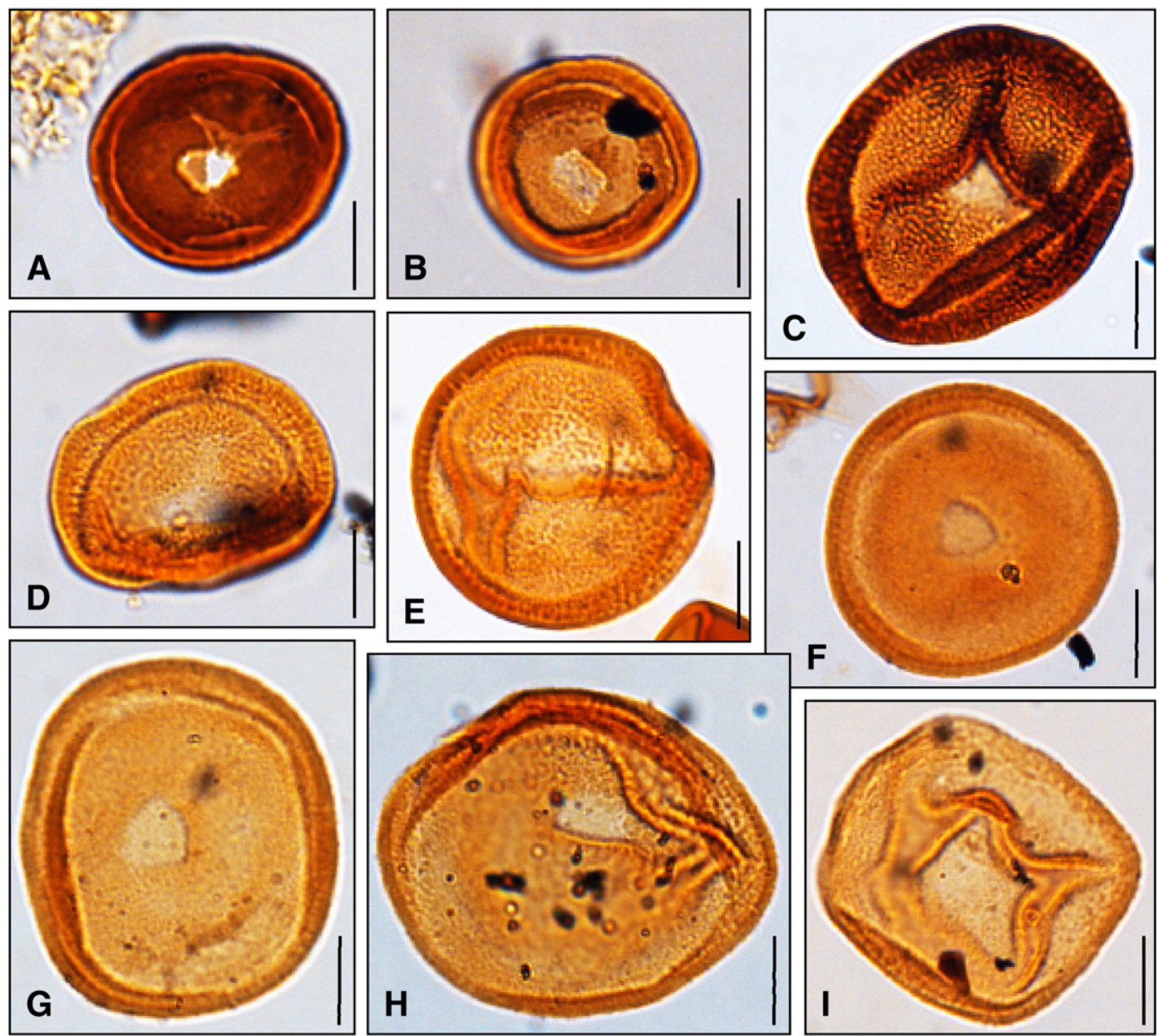

$+$

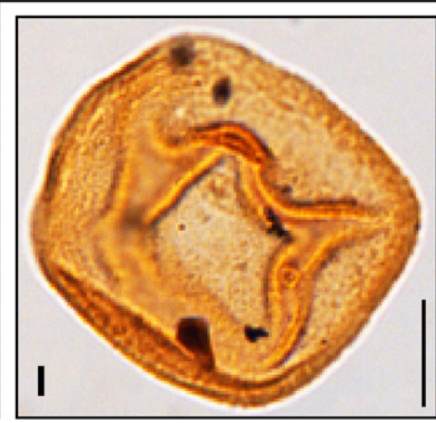

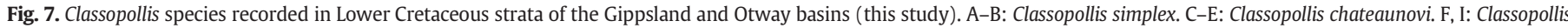

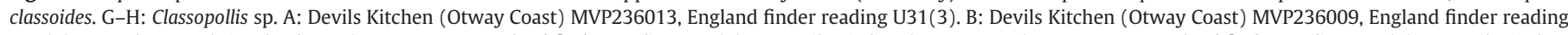

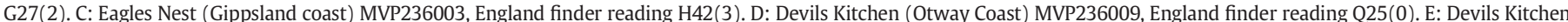

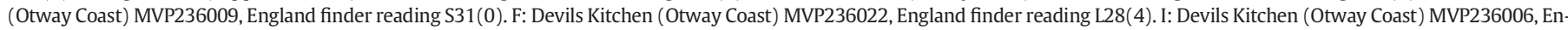

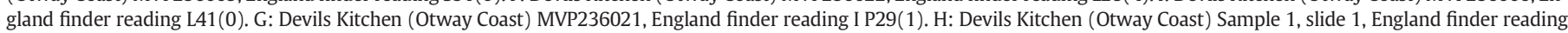
V39(3). All scale bars $=10 \mu \mathrm{m}$. 


\section{Synonymy:}

For full synonymy see Raine et al. (2011).

non 1975 Classopollis simplex (Danze-Corsin and Laveine) Reiser and Williams; Burger in Norwick and Burger, p. 142, pl. 13, Figs. 1, 2; textFig. 28.

Description: See Reiser and Williams (1969).

Comments: It is assumed that specimens in this study that conform to Classopollis simplex are reworked from older sediments, since this species is typical of Early Jurassic assemblages of northeastern Australia (de Jersey, 1973), the grains are in poor condition, and reworking of older palynomorphs is common in the samples.

Distribution: C. simplex is recorded from Eagles Nest in the Gippsland Basin (Aptian) and from Devils Kitchen, Racecourse Steps and Moonlight Head in the Otway Basin (Albian).

Classopollis classoides Pflug, 1953 emend. Pocock and Jansonius, 1961 (Fig. 7F, I)

Synonymy:

1994 Classopollis classoides Mildenhall, 1994, pl. 15, Figs. 13, 14.

For full synonymy and comments regarding synonymy see Raine et al. (2011).

Description: Grains anisopolar, amb circular, compressed in polar direction (spherical?). Exine 1-2 $\mu \mathrm{m}$ thick in the equatorial region and thinning towards the pole, with a sculpture of regularly distributed, isomorphous, granulae. Sculpture in the equatorial region is aligned in continuous rows parallel to the equator to form continuous annular bands of overall width $5 \mu \mathrm{m}$. A rimula is always present. Proximal pole usually has a triangular area (sides 5-9 $\mu \mathrm{m}$ ) in which the exine is absent. Distal pole is rarely characterized by the presence of a circular pore.

Grain size: Equatorial diameter 32(37.5)45 $\mu \mathrm{m}$ (14 specimens measured).

Comments: Burger (1966) noted the possible synonymy of Classopollis classoides and C. torosus. However, as discussed by Peyrot et al. (2007), the loss of the type material precludes any comparison. C. classoides was described by Pocock and Jansonius (1961) as having a granulate sculpture whereas C. torosus was described by Couper (1958) and Burger (1965) as having a scabrate exine, as was C. sp. cf. C. torosus (Balme, 1957). Pocock and Jansonius (1961) described continuous bands of sculpture around the equator of $C$. classoides whilst Couper (1958) and Burger (1965) suggested that $C$. torosus has forms that have continuous endostriae or features that are not continuous but are formed by discrete granules. Peyrot et al. (2007) attempted to distinguish the two species based on SEM, TEM and CSLM and determined that their Type B grains were related to $C$. torosus, based on a thinner scabrate exine than their Type A, which had features that resembled the description of $C$. classoides by Pocock and Jansonius (1961). This is in agreement with the measurements by Reyre (1970) who indicated that $C$. classoides has a thicker exine $(1-2 \mu \mathrm{m})$ than $C$. torosus $(0.75-1.0 \mu \mathrm{m})$. As this study is reliant on light microscopy Classopollis grains that have a granulate sculpture, continuous equatorial striae made of granulae and a consistently thicker exine $(>1 \mu \mathrm{m})$ are placed in $C$. classoides. The equatorial diameter of the grains is, however, much larger than described by Pocock and Jansonius (1961).

Distribution: In this study, C. classoides is recorded from Moonlight Head and Devils Kitchen, Otway Basin (Albian).

Classopollis sp. (Fig. 7G-H)

Synonymy:

1975 Classopollis sp., Burger in Norvick and Burger, pl. 30, Fig. 4.

Description: Grains anisopolar, amb circular or angularly subcircular, exine $1 \mu \mathrm{m}$ thick. The exine of the distal surface is broadly folded with no discernible consistency to the pattern of the folding direction in relation to the amb. Sculpture is regularly distributed, isomorphous, and consisting of minute granules and rare spines. Sculpture in the equatorial region is aligned more or less distinctly in rows parallel to the equator and closely spaced. Rimula is not observed. Proximal polar area is not differentiated. Distal pole is characterized by the presence of an area of thinned exine ( 1 specimen) or a poorly defined circular pore $11 \mu \mathrm{m}$ in diameter ( 1 specimen).
Grain size: $32-37 \mu \mathrm{m}$ (2 specimens measured).

Comments: This is a rare form in the assemblage from Albian strata at Devils Kitchen. Burger (in Norvick and Burger, 1975) described a Classopollis species that has a sculpture of minute grana and spines that are arranged in rows in the equatorial region and lacks a rimula. However, the majority of the illustrated specimens are intensely folded at right angles to the equator and it was suspected that it was a recycled element. The two specimens of this type found in this study most closely resemble the specimen shown in plate 30, Fig. 4 of Burger's (in Norvick and Burger, 1975) study, in which the grain is not so strongly folded.

Distribution: In this study, Classopollis sp. is recorded from Devils Kitchen, Otway Basin (Albian).

\section{Discussion}

\subsection{Taxonomic affinities}

Given the remarkable range of morphology, habit and habitat represented among the Cheirolepidiaceae (Watson, 1988, p. 382), no single foliar or distributional character can definitively discriminate members of this family from those of other conifer clades. Although the leaves of cheirolepids are consistently small and awl-shaped, there is considerable variability in the phyllotaxy, epidermal ornamentation and stomatal distribution, such that several fossils of this group have been erroneously assigned to various alternative conifer families, e.g. Cupressaceae and Araucariaceae by previous workers. Fossil foliage attributed to Pagiophyllum araucarinum and Pagiophyllum maculosum (van Konijnenburg-van Cittert, 1987; Watson, 1988), Brachyphyllum crucis (Watson, 1988), possibly Brachyphyllum patens (van der Ham et al., 2003), Watsoniocladus valdensis (Seward) Srinivasan, 1995 (Watson and Alvin, 1999) and Geinitzia spp. (Watson, 1988) fall into this category. However, other members of these genera are confidently placed in Podocarpaceae and Araucariaceae (Harris, 1979). This diversity of form may explain why cheirolepidiacean foliage has not been widely identified in Australian fossil floras by previous workers. Where more complete plant remains have been found, Cheirolepidiaceae reveal a variety of phyllotaxy patterns from spirally arranged leaves to whorls of leaves in twos or threes (Watson, 1988; Daviero et al., 2001). Similarities in branching morphology and leaf arrangement exist between Frenelopsis and extant Cupressaceae. In living conifers the branches always emerge from the axils of the leaves; no modern gymnosperms display branching in the internodal area as in Frenelopsis, rather it is only seen in some modern herbaceous angiosperms (Daviero et al., 2001).

Material attributed to Otwayia in this study was interpreted by Cantrill and Douglas (1988) to be of possible taxodiacean (=cupressacean) affinity. Morphological features of Cheirolepidiaceae can be easily confused with those of modern Cupressaceae. For example, Cupressinocladus was originally named for its similarity to members of the Cupressaceae based on characters, such as stomatal arrangement (see, e.g., examples from the Lower Purbeck of England: Francis, 1983). However, Srinivasan (1995) removed some species from Cupressinocladus to the cheirolepidiacean genus Watsoniocladus based on cuticular morphology as described by Watson (1988) and Okubo and Kimura (1991). Major differences between Watsoniocladus and extant Cupressaceae include: stomata distributed all over the abaxial surface rather than in two marginal bands; stomata surrounded by a raised ring or flat, rather than concrescent papillae that form a Florin ring; papillae projecting from subsidiary cells, overarching the stomatal aperture, or papillae inside the stomatal pit-features not seen in Cupressaceae; papillae or trichomes in nonstomatal zones, compared to being restricted to the stomatal zones; inner periclinal walls of epidermal cells are smooth, rather than sculptured; and crystal cavities (calcium oxalate) are absent in Watsoniocladus (Srinivasan, 1995).

Cheirolepidiaceae and Cupressaceae have a range of similarities, including small, scale-like leaves, similar phyllotaxy (in some genera), sunken stomata, and small plant stature in many species. 
Cheirolepidiacean phyllotaxy varies (Watson, 1988), from predominantly whorled in the frenelopsids, to opposite decussate in nonfrenelopsids. Cupressaceae generally has opposite or helically inserted lanceolate, dorsiventrally flattened and univeined leaves (Ma et al., 2009), apart from a clade with whorled (e.g., in Callitris, Actinostrobus and Fitzroya: de Laubenfels, 1953; He et al., 2012) or opposite-decussate leaves (Widdringtonia, Diselma and Papuacedrus: Srinivasan, 1995; Wilf et al., 2009; He et al., 2012). Escapa et al. (2008) emphasized the need to assess vegetative and reproductive characters collectively to demonstrate confident attribution to Cupressaceae.

Opposite decussate phyllotaxy is expressed in frenelopsid cheirolepids (Alvin and Pais, 1978; Mendes et al., 2010) but this subgroup has segmented shoots with extremely reduced leaves forming a collar around the stem, and stomata that lack a distinct Florin ring. In some cases, two to three sheathed leaves arise from the nodes of Frenelopsis stems (Mendes et al., 2010). Cuticular descriptions of frenelopsids (Gomez et al., 2002b) share with Otwayia only the strongly overarching subsidiary cell papillae in the stomatal complex. Leaves of 0 . tetragona and 0 . hermata are spirally arranged on the axis, identifying them as nonfrenelopsids, according to Watson (1988).

The cuticular morphology of Cupressaceae also differs from Cheirolepidiaceae. For example, the non-frenelopsid Watsoniocladus was erected by Srinivasan (1995) on the basis of cuticular characters, such as: having stomata arranged mainly on the abaxial surface, the presence of a raised ring around stomata, and papillae either overarching the stomatal aperture or positioned within the pit. This differs from morphologically similar foliage attributed to Cupressinocladus (Cupressaceae), which is a form genus that lacks cuticle on the type specimen (Watson, 1988; Srinivasan, 1995; Watson and Alvin, 1999). However, extant examples of Cupressaceae have stomata distributed in bands with an interstomatal zone on the abaxial surface. Papillae on the subsidiary cells form a raised rim (Florin ring) around the stomate, but lack the papillae overarching the stomatal pit (Srinivasan, 1995). Recent work has highlighted distinctive cuticular characters of other fossil cupressaceous leaves, including: stomata in bands, elliptical stomatal pores, subsidiary cells that are commonly raised to form a prominent Florin ring, and epidermal cells near the stomata being commonly papillate (e.g., Kvaček et al., 2000; McIver, 2001; Ma et al., 2009; Shi et al., 2011; He et al., 2012; Serbet et al., 2013). According to Pole (2000), other differences are evident between Cupressaceae and Cheirolepidiaceae. 'Taxodiaceous' Cupressaceae have cyclocytic stomata that are not in rows, are not surrounded by a raised rim and are randomly oriented. This contrasts with Cheirolepidiaceae stomata that have subsidiary cells that are papillate, whereby papillae project laterally across the stomatal pore (Pole, 2000).

The unique combination of awl-shaped leaves, deeply sunken stomata in a variety of consistent arrangements, randomly oriented stomatal openings, each heavily protected and/or obscured by one or two ranks of papillae on subsidiary cells, commonly forming a Florin ring (though not in some Pseudofrenelopsis; Yang et al., 2009), appears to be a relatively robust measure for attributing foliage to Cheirolepidiaceae (Alvin, 1982; Watson, 1988; Guignard et al., 1998; Watson and Alvin, 1999; Pole, 2000; Du et al., 2013). Nonetheless, the broad architectural similarities in foliage and phyllotaxy suggest a potentially close relationship between Cheirolepidiaceae and Cupressaceae that should be evaluated by further phylogenetic analysis.

Cheirolepidiaceae may be more readily separated from Cupressaceae on reproductive architecture, whereby ovuliferous cones of the former consist of helically arranged bract scale complexes where the bract and scale are separated, in some cases with fusion occurring between two fertile bracts (each bearing two adaxially attached ovules covered by an epimatium) and sterile scales but retaining a free scale apex (del Fueyo et al., 2008; Escapa et al., 2012). Cheirolepidiaceans have flattened bilateral dwarf shoots with several scales (del Fueyo et al., 2008; Escapa et al., 2013) and one or two seeds per ovuliferous scale (Rothwell et al., 2011; Escapa et al., 2012). Unique to the Cheirolepidiaceae is the primitive character of an inner cuticle on the dwarf shoot (Clement-Westerhof and van Konijnenburg-van Cittert, 1991), the presence of scale tissue covering but not enclosing the seed (Escapa et al., 2012), and the shedding of ovuliferous dwarf shoots from the cone when ripe, but having persistent sterile bracts (del Fueyo et al., 2008). Cupressaceae sensu lato typically have ovulate cones that are weakly lignified at maturity (Kvaček, 2000), and consist of helically arranged partially fused bract-scale complexes bearing numerous, small, flattened ovules adaxially (Yao et al., 1998; Escapa et al., 2008).

Pollen cones consist of helically arranged peltate sporophylls with pollen sacs attached abaxially on the microsporophyll in both Cupressaceae and Cheirolepidiaceae. Cupressacean microsporangiate cones are generally smaller with up to six pollen sacs per sporophyll (Rothwell et al., 2007; Escapa et al., 2008), whereas cheirolepid pollen cones may have had 2-3 pollen sacs per sporophyll, though this character is uncertain or unknown in some frenelopsids (Axsmith et al., 2004b; Axsmith and Jacobs, 2005) and non-frenelopsids (Archangelsky, 1968). However, it is its pollen morphology that most clearly separates the families: spherical pollen with a ring-like germinal groove and a complex columellate-like exine structure in Cheirolepidiaceae (Taylor and Alvin, 1984; Krassilov, 1987; ClementWesterhof and van Konijnenburg-van Cittert, 1991) versus spherical, weakly scabrate, non-tectate pollen, with an inconspicuous germinal pore in Cupressaceae (Yao et al., 1998; Kunzmann et al., 2009).

The similar timing in appearance of both Cupressaceae (now including Taxodiaceae; Farjon, 2005) and Cheirolepidiaceae in the mid-Mesozoic of southern South America indicates co-radiation of these possibly related groups (Escapa et al., 2008, 2013) and their potential co-existence across southern Gondwana during the mid-Mesozoic. Austrohamia described from the Cañadón Asfalto Formation (Jurassic age), Chubut Province, Argentina, is the oldest macrofossil record of Cupressaceae from the Southern Hemisphere (Escapa et al., 2008). The oldest confident Cupressaceae macrofossils from Australia are leaves and cones of Austrosequoia wintonensis from the Winton Formation (Cenomanian) Eromanga Basin (Peters and Christophel, 1978; McLoughlin et al., 1995, 2010).

Confident Gondwanan records of Cheirolepidiaceae (Fig. 8) include Tomaxellia (Archangelsky, 1963, 1968; Kunzmann et al., 2006), Frenelopsis (Kunzmann et al., 2006) and Otwayia (Pole, 2000; McLoughlin et al., 2002). However, a range of other mid-Mesozoic austral awl- and scaleleafed conifers may belong to this family in the absence of definitive reproductive or cuticular details, including various species of Pagiophyllum (McLoughlin et al., 2000; McLoughlin and Pott, 2009) and Brachyphyllum (Baldoni, 1980; Gould, 1980; Gomez et al., 2002a,c; Rees and Cleal, 2004) and even Araucaria-like forms (McLoughlin, 1996; McLoughlin and Hill, 1996; McLoughlin and McNamara, 2001). Only non-frenelopsid cheirolepids have been recorded from the Mesozoic of southern Gondwana, suggesting that this clade had a greater range of environmental tolerance, including moist climates and polar photoperiod regimes, than the mostly aridity- and salinity-adapted frenelopsids (see Subsection 5.4 Palaeoenvironmental signals).

\subsection{Association with Classopollis pollen}

Classopollis (Cheirolepidiaceae) pollen is distinguished by a clear autapomorphy-a circular germinal groove on the spherical grain. This distinctiveness, together with their greater abundance than macrofossils, endows dispersed pollen with the best means of identifying the past distribution of Cheirolepidiaceae. Cones with in situ Classopollis have not been recorded from Australia. However, the fossil record of dispersed pollen is extensive (Helby et al., 1987; Backhouse, 1988; Dettmann et al., 1992; Burger, 1994; Jansson et al., 2008).

Classopollis is a significantly more important component of lowlatitude Early Cretaceous palynofloras than araucarian and podocarp pollen, which dominate high southern palaeolatitude palynoassemblages (Alvin, 1982; Dettmann et al., 1992; Cantrill and Poole, 2002). Nevertheless, some cheirolepidiacean pollen (Classopollis/Corollina) is clearly 


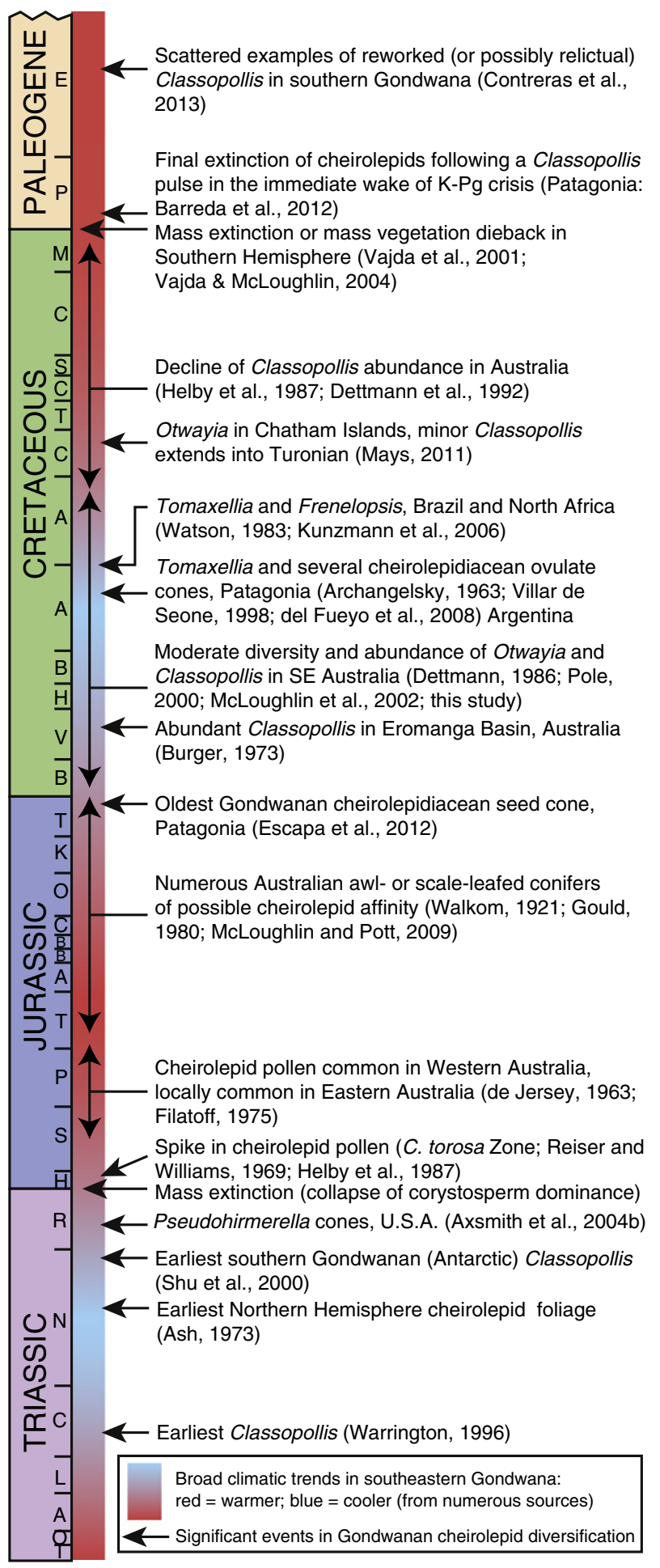

Fig. 8. Chart of major events in the diversification of Cheirolepidiaceae at southern high latitudes with emphasis on the Australian fossil record (Burger, 1973; Contreras et al., 2013; de Jersey, 1963; Mays, 2011; Shu et al., 2000; Vajda and McLoughlin, 2004; Vajda et al., 2001; Walkom, 1921; Warrington, 1996).

represented in high-palaeolatitude Cretaceous assemblages highlighting the penetration of cheirolepids into polar vegetation (Cantrill and Poole, 2002). Apart from a notable spike in abundance during the Hettangian (Filatoff, 1975; Burger, 1994; McLoughlin et al., in press), Classopollis occurs essentially as a background element in southern Australian palynomorph assemblages from the latest Triassic up to at least the Maastrichtian (Fig. 7; Helby et al., 1987; Dettmann, 1992; Turner et al., 2009). Several factors may account for the family's relatively low abundance in the Australian Mesozoic. The plants may have been ecologically and numerically subordinate in high-latitude Gondwanan vegetation. Further, low quantities of pollen may have been produced per individual plant. In this regard, Labandeira et al. (2007) suggested that Cheirolepidiaceae may have been insect pollinated based on the enclosed nature of the ovules. Nevertheless, cheirolepids may have been more important in some high-latitude habitats than regional palynofloral surveys have suggested. In this regard, Classopollis is very rare $(<1 \%)$ in the Valanginian-Barremian strata of Boola Boola, Gippsland, as Aptian records show ranges from $0.8 \%$ to $2.8 \%$ in Koonwarra, Gippsland (Dettmann, 1986), but Classopollis makes up from 3 to $14 \%$ of the Albian palynomorph assemblage at Devils Kitchen. Further, their diversity is now known to be greater than previously assumed based on the recognition of six cheirolepidiacean leaf/cuticle forms and four pollen species in the Early Cretaceous of eastern Australia (Table 1).

\subsection{Association with Mycorrhizal roots}

Cantrill and Douglas (1988) noted the symbiotic association of fungi and conifer roots in the form of distinct mycorrhizal nodules at the Devils Kitchen (Albian) locality in the Otway Basin. These roots were found in the same beds as abundant $O$. tetragona foliage. Since most of the Otwayia remains do not appear to have undergone significant transport, Cantrill and Douglas (1988) argued that these fossils belonged to the same plant. A strong relationship with mycorrhizal fungi may have enabled cheirolepids to successfully colonize disturbed or lownutrient substrates in high-latitude alluvial valley settings. Cheirolepid remains at the Devils Kitchen site are typically preserved in sandy to silty levee and laterally adjacent floodbasin facies of a predominantly high-energy braided fluvial depositional system. The levee deposits show weak palaeosol development and contain extensive nodular root traces and clitellate egg cases that imply better aerated and less acidic conditions than intercalated strongly carbonaceous floodbasin lake and mire facies (Behrensmeyer and Hook, 1992; Tosolini and Pole, 2010).

Mycorrhizal nodules occur on many extant plants including the conifer families Podocarpaceae, Araucariaceae and Sciadopityaceae (Dickie and Holdaway, 2011). This form of fungi-conifer interaction extends back to at least the Middle Triassic (Schwendemann et al., 2011) and evidence for mycorrhizae in general extends back to the dawn of terrestrial plant communities (Remy et al., 1994). Mycorrhizae play an important role in phosphate and possibly nitrogen-fixing (Spratt, 1912; Bergersen and Costin, 1964; Becking, 1965; Mosse, 1973; Slankis, 1974), and may also act in calcium-fixing (Blum et al., 2002). Spherical nodules produced by increasing the volume of the root cortex may also be an adaptation to maximize the interaction with arbuscular mycorrhizal hyphae at the least cost to the plant (Dickie and Holdaway, 2011). Such associations convey obvious benefits for plants growing on low-nutrient substrates or occupying disturbed riparian habitats where rapid growth and opportunistic ecological strategies are advantageous (Morrison and English, 1967; Blum et al., 2002). Such mycorrhizal nodules are particularly characteristic of exposed sites with mafic rocky and episodically inundated substrates in modern tropical-subtropical areas low in phosphorous (Bergersen and Costin, 1964).

\subsection{Palaeoenvironmental signals}

A range of data from foliar physiognomy, the presence of abundant epiphyllous fungi, mycorrhizal root nodules, semi-aquatic ferns and lycophytes, and sedimentary features suggest that consistently moist climates prevailed during the Early Cretaceous in southeastern Australia (Dettmann et al., 1992; Tosolini, 2001). Although features such as diminutive leaf size, leaf imbrication and thick cuticles with papillate protection of stomata, evident in Otwayia and related dispersed cuticle, are normally linked to dry, saline or windy sites, we hypothesize that such features in 
the Victorian species reflect adaptations to humid conditions, but where low-nutrient substrates and strong seasonality locally favoured plants with xeromorphic characters.

Cheirolepids are an extinct group, hence their ecology can only be inferred from fossil remains. The family probably included plants with a considerable range of habits (small shrubs to trees), occupying a wide variety of environments (Gomez et al., 2002b; Axsmith, 2006). Based on their diminutive leaves, strong stomatal protection and association with evaporite deposits at low latitudes, cheirolepids have been linked to arid or coastal environments by many authors (Alvin, 1982; Francis, 1983, 1984; Watson, 1988). They have also been linked to sites disturbed by high volcanic ash fall at higher palaeolatitudes (Archangelsky and Taylor, 1986). Although such foliar morphological features occur in truly arid-adapted plants, in Otwayia, they may have aided the reduction of resource loss through respiration and transpiration during the long period of winter darkness at high latitudes. These features may alternatively, or additionally, be a response to growth on low-nutrient soils, which have limiting effects on photosynthetic capacity and respiration rates in modern plants commonly resulting in scleromorphy (Groves, 1981; Wright et al., 2001). Recent palaeoecological evidence from Texas (Axsmith and Jacobs, 2005) and the Iberian Peninsula (Gomez et al., 2001, 2002b; Mendes et al., 2010) not only revealed succulence and other xeromorphic characters in some frenelopsids, but also highlighted the diversity of environments in which these conifers are found (Table 1, Mendes et al., 2010): ranging from freshwater, braided or meandering rivers, distal floodplains and swamps, to deltas, brackish estuaries and lagoons, with some dispersed remains even found in tidal flats, fully marine back-reef lagoons and shelf settings.

Species of Otwayia were present throughout the Early Cretaceous of eastern Australia and are known to have ranged as far as the eastern fringe of Zealandia (Pole and Philippe, 2010). In most cases, they retained their diminutive leaves on the parent plant (i.e., without obvious abscission scars). The fossil remains of these plants represent branched twigs of various sizes suggesting that they were not shed as discrete units akin to those of the contemporaneous podocarp or cupressacean Bellarinea (Nagalingum et al., 2005) and had an evergreen rather than deciduous habit. They co-existed with a flora of large conifers, several seed-ferns, and a modest range of ferns and herbaceous lycophytes (Douglas, 1969, 1973; Drinnan and Chambers, 1986; Cantrill, 1991, 1992; McLoughlin et al., 2002; Tosolini et al., 2002).

Our results and a growing body of evidence from other studies (e.g., Archangelsky, 1968; Archangelsky and Taylor, 1986; Cantrill and Poole, 2002; Escapa et al., 2012) reveal that cheirolepids were a significant subsidiary component of the mid- to late Mesozoic austral high-latitude vegetation. They may locally have achieved positions of dominance in disturbed habitats, low nutrient substrates, and in altered vegetation after mass extinction events (Turner et al., 2009; Barreda et al., 2012).

\section{Conclusions}

Five species of Cheirolepidiaceae are recognized in the Early Cretaceous strata of the Gippsland and Otway basins, southeastern Australia based on foliar cuticular differences. One of these taxa and an additional three forms were also reported from the Eromanga Basin, northeastern Australia by Pole (2000). Four cheirolepid (Classopollis) species are recognized from the same strata hosting Otwayia species in the Gippsland and Otway basins, although one of these pollen types ( $C$. simplex) is likely reworked. These discoveries indicate that the cheirolepids formed an important subsidiary component of Australian high-latitude floras through the Early Cretaceous.

These conifers survived in cool humid climates in contrast to semi-arid or coastal settings of low palaeolatitudes, where cheirolepids (especially frenelopsids) are best known. Otwayia species (nonfrenelopsid cheirolepids) are interpreted to have been shrubs to small trees, i.e., of a lesser stature than araucarians and podocarps that dominated the regional vegetation (Drinnan and Chambers, 1986; Cantrill, 1991, 1992; McLoughlin et al., 2002). Their xeromorphic characters, such as diminutive leaves with papillate sunken stomata, an evergreen habit, and association with mycorrhizal root nodules suggest that the Otwayia lived on nutrient-poor soils of regularly disturbed braided fluvial systems, within the Australian-Antarctic rift system.

\section{Acknowledgements}

The authors thank the sponsors of this project: Minerals and Petroleum Victoria, OMV Australia Pty Ltd. (formerly Cultus Petroleum), SANTOS Limited and Oil Company of Australia. The project formed part of a PhD undertaken by A-M.P.T. that was funded by the Australian Postgraduate Award (Industry), and fit into the larger Australian Research Council Large Grant for the investigation of Australian Mesozoic floras, which was awarded to SM. Jocelyn Carpenter gave valuable help with scanning electron microscopy. ARC Linkage grant LP0989203 to DJC, SJG and BEW, funded this research with industry partners Lakes Oil N.L., Nexus Energy and Geotrack International. SM acknowledges the funding support from a Swedish Research Council (VR) grant and an Australian Research Council Linkage grant. Two anonymous reviewers are thanked for their constructive comments which improved the manuscript.

\section{References}

Alvin, K., 1977. The conifers Frenelopsis and Manica in the Cretaceous of Portugal Palaeontology 20, 387-404.

Alvin, K.L., 1982. Cheirolepidiaceae: biology, structure and paleoecology. Review of Palaeobotany and Palynology 37, 71-98.

Alvin, K., Pais, J., 1978. A Frenelopsis with opposite decussate leaves from the Lower Cretaceous of Portugal. Palaeontology 21, 873-880.

Alvin, K., Spicer, R., Watson, J., 1978. A Classopollis-containing male cone associated with Pseudofrenelopsis. Palaeontology 21, 847-856.

Alvin, K., Fraser, C., Spicer, R., 1981. Anatomy and palaeoecology of Pseudofrenelopsis and associated conifers in the English Wealden. Palaeontology 24, 759-778.

Alvin, K.L., Watson, J., Spicer, R.A., 1994. A new coniferous male cone from the English Wealden and a discussion of pollination in the Cheirolepidiaecae. Palaeontology 37 173-180.

Archangelsky, S., 1963. A new Mesozoic flora from Ticó, Santa Cruz Province, Argentina. Bulletin of the British Museum (Natural History) Geology 8, 47-92.

Archangelsky, S., 1966. New gymnosperms from the Ticó flora, Santa Cruz Province, Argentina. Bulletin of the British Museum (Natural History) Geology 13, 259-295.

Archangelsky, S., 1968. On the genus Tomaxellia (Coniferae) from the Lower Cretaceous of Patagonia (Argentina) and its male and female cones. Botanical Journal of the Linnean Society of London 61, 153-165.

Archangelsky, S., Taylor, T.N., 1986. Ultrastructural studies of fossil plant cuticles. II. Tarphyderma gen. n., a Cretaceous conifer from Argentina. American Journal of Botany 73, 1577-1587.

Archangelsky, S., Taylor, T.N., 1991. Tarphyderma punctatum (Michael) Archangelsky \& Taylor, comb. nov., an Early Cretaceous conifer. Taxon 40, 319-320.

Ash, S.R., 1973. Two new Late Triassic plants from the Petrified Forest of Arizona. Journal of Paleontology 47, 46-53.

Askin, R.A., 1992. Late Cretaceous-early Tertiary Antarctic outcrop evidence for past vegetation and climates. Antarctic Research Series 56, 61-73.

Axsmith, B.J., 2006. The vegetative structure of a Lower Cretaceous conifer from Arkansas; further implications for morphospecies concepts in the Cheirolepidiaceae. Cretaceous Research 27, 309-317.

Axsmith, B.J., Jacobs, B.F., 2005. The conifer Frenelopsis ramosissima (Cheirolepidiaceae) in the Lower Cretaceous of Texas: systematic, biogeographical, and paleoecological implications. International Journal of Plant Sciences 166, 327-337.

Axsmith, B.J., Andrews, F.M., Fraser, N.C., 2004a. The structure and phylogenetic significance of the conifer Pseudohirmerella delawarensis nov. comb. from the Upper Triassic of North America. Review of Palaeobotany and Palynology $129,251-263$.

Axsmith, B.J., Krings, M., Waselkov, K., 2004b. Conifer pollen cones from the Cretaceous of Arkansas: implications for diversity and reproduction in the Cheirolepidiaceae. Journal of Paleontology 78, 402-409.

Backhouse, J., 1988. Late Jurassic and Early Cretaceous palynology of the Perth Basin, Western Australia. Geological Survey of Western Australia Bulletin 135, 1-233.

Baldoni, A.M., 1980. Tafoflora Jurassica de la zona de Picun Leufu, provincial de Neuquen. Ameghiniana 17, 243-254

Balme, B.E., 1957. Spores and pollen grains from the Mesozoic of Western Australia. Coal Research Section CSIRO, Reference T.C., 25, pp. 1-48.

Bamford, M.K., 2004. Diversity of the woody vegetation of Gondwanan southern Africa Gondwana Research 7, 153-164. 
Barreda, V.D., Cúneo, N.R., Wilf, P., Currano, E.D., Scasso, R.A., Brinkhuis, H., 2012. Cretaceous/ Paleogene floral turnover in Patagonia: drop in diversity, low extinction, and a Classopollis spike. PLoS One 7, e52455.

Bartiromo, A., Barale, G., Barone Lumaga, M.R., Bravi, S., Barattolo, F., 2012. An Early Cretaceous flora from Cusano Mutri, Benevento, southern Italy. Cretaceous Research 33, 116-134.

Becking, J., 1965. In vitro cultivation of alder root-nodule tissue containing the endophyte. Nature 207, 885-887.

Behrensmeyer, A., Hook, R., 1992. Paleoenvironmental contexts and taphonomic modes. In: Behrensmeyer, A. (Ed.), Terrestrial Ecosystems Through Time: Evolutionary Paleoecology of Terrestrial Plants and Animals. University of Chicago Press, Chicago, pp. 15-136.

Bergersen, F., Costin, A., 1964. Root nodules on Podocarpus lawrencei and their ecological significance. Australian Journal of Biological Sciences 17, 44-48.

Blum, J.D., Klaue, A., Nezat, C.A., Driscoll, C.T., Johnson, C.E., Siccama, T.G., Eagar, C., Fahey, T.J., Likens, G.E., 2002. Mycorrhizal weathering of apatite as an important calcium source in base-poor forest ecosystems. Nature 417, 729-731.

Bryan, S., Constantine, A., Stephens, C., Ewart, A., Schön, R., Parianos, J., 1997. Early Cretaceous volcano-sedimentary successions along the eastern Australian continenta margin: implications for the break-up of eastern Gondwana. Earth and Planetary Science Letters $153,85-102$.

Burger, D., 1965. Some new species of Classopollis from the Jurassic of the Netherlands. Leidse Geologische Medelingen 33, 63-69.

Burger, D., 1966. Palynology of uppermost Jurassic and lowermost Cretaceous strata in the Eastern Netherlands. Leidse Geologische Medelingen 35, 209-276.

Burger, D., 1973. Spore zonation and sedimentary history of the Neocomian, Great Artesian Basin, Queensland. Geological Society of Australia Special Publication 4, $87-118$.

Burger, D., 1980. Palynology of the Lower Cretaceous in the Surat Basin. Bureau of Minera Resources Geology and Geophysics Bulletin 189, 1-106.

Burger, D., 1993. Early and middle Cretaceous angiosperm pollen grains from Australia. Review of Palaeobotany and Palynology 78, 183-234.

Burger, D., 1994. Palynological studies of the Bundamba Group and Walloon Coal Measures in the Clarence-Moreton Basin. In: Wells, A.T., O'Brien, P.E. (Eds.), Geology and Petroleum Potential of the Clarence-Moreton Basin, New South Wales and Queensland. AGSO Bulletin, 241, pp. 164-180.

Cantrill, D.J., 1991. Broad leafed coniferous foliage from the Lower Cretaceous Otway Group, southeastern Australia. Alcheringa 15, 177-190.

Cantrill, D.J., 1992. Araucarian foliage from the Lower Cretaceous of southern Victoria, Australia. International Journal of Plant Science 153, 622-645.

Cantrill, D.J., Douglas, J.G., 1988. Mycorrhizal conifer roots from the Lower Cretaceous of the Otway Basin, Victoria. Australian Journal of Botany 36, 257-272.

Cantrill, D.J., Falcon-Lang, H.J., 2001. Cretaceous (late Albian) Coniferales from Alexande Island, Antarctica. 2. Leaves, reproductive structures and roots. Review of Palaeobotany and Palynology 115, 119-145.

Cantrill, D.J., Poole, I., 2002. Cretaceous patterns of floristic change in the Antarctic Peninsula. In: Crame, J.A., Owen, A.W. (Eds.), Palaeobiogeography and Biodiversity Change: the Ordovician and Mesozoic-Cenozoic Radiations. Geological Society, London, UK pp. 141-152.

Cantrill, D.J., Poole, I., 2005. Taxonomic turnover and abundance in Cretaceous to Tertiary wood floras of Antarctica: implications for changes in forest ecology. Palaeogeography, Palaeoclimatology, Palaeoecology 215, 205-219.

Cantrill, D.J., Webb, J.A., 1987. A reappraisal of Phyllopteroides Medwell (Osmundaceae) and its stratigraphic significance in the Lower Cretaceous of eastern Australia. Alcheringa 11, 59-85.

Carpenter, R.J., Hill, R.S., 1999. Ginkgo leaves from Paleogene sediments in Tasmania. Australian Journal of Botany 47, 717-724.

Clement-Westerhof, J.A., van Konijnenburg-van Cittert, J.H.A., 1991. Hirmeriella muensteri: new data on the fertile organs leading to a revised concept of the Cheirolepidiaeae. Review of Palaeobotany and Palynology 68, 147-179.

Contreras, L., Pross, J., Bijl, P.K., Koutsodendris, A., Raine, J.I., van de Schootbrugge, B., Brinkhuis, H., 2013. Early to middle Eocene vegetation dynamics at the Wilkes Land Margin (Antarctica). Review of Palaeobotany and Palynology 197 119-142.

Couper, R.A., 1958. British Mesozoic microspores and pollen grains, a systematic and stratigraphic study. Palaeontographica Abteilung B 103, 75-179.

Cúneo, N.R., de Seoane, L.V., Gandolfo, M.A., Wilf, P., 2010. Last ginkgoalean record in South America. Botanical Society of America Meeting, Providence, Rhode Island, p. 507 (abstract).

Danzé-Corsin, P., Laveine, J.P., 1963. Microflore. In: Briche, P., Danzé-Corsin, P., Laveine, J.P. (Eds.), Flore infraliassique du Boulonnais. Société Géologique du Nord Mémoire, 13, pp. 57-143.

Daviero, V., Gomez, B., Philippe, M., 2001. Uncommon branching pattern within conifers: Frenelopsis turolensis, a Spanish Early Cretaceous Cheirolepidiaceae. Canadian Journal of Botany 79, 1400-1408.

de Jersey, N.J., 1963. Jurassic spores and pollen grains from the Marburg Sandstone. Geological Survey of Queensland Publication 313, 1-15.

de Jersey, N.J., 1973. Rimulate pollen grains from the lower Mesozoic of Queensland. Geological Society of Australia Special Publication 4, 127-140.

de Laubenfels, D.J., 1953. The external morphology of coniferous leaves. Phytomorphology 3 , $1-20$.

del Fueyo, G.M., Archangelsky, S., Llorens, M., Cúneo, R., 2008. Coniferous ovulate cones from the Lower Cretaceous of Santa Cruz province, Argentina. International Journal of Plant Science 169, 799-813.

Dettmann, M.E., 1963. Upper Mesozoic microfloras from south-eastern Australia. Proceedings of the Royal Society of Victoria 77, 1-148.
Dettmann, M.E., 1986. Early Cretaceous palynoflora of subsurface strata correlative with the Koonwarra Fossil Bed, Victoria. Association of Australasian Palaeontologists, Memoirs 3, 79-110.

Dettmann, M.E., 1992. Structure and floristics of Cretaceous vegetation of southern Gondwana: implications for angiosperm biogeography. Palaeobotanist 41, 224-233.

Dettmann, M.E., 1994. Cretaceous vegetation: the microfossil record. In: Hill, R.S. (Ed.), History of the Australia Vegetation: Cretaceous to Recent. Cambridge University Press, Cambridge, pp. 143-170.

Dettmann, M.E., Molnar, R.E., Douglas, J.G., Burger, D., Fielding, C., Clifford, H.T., Francis, J., Jell, P., Rich, T., Wade, M., Rich, P.V., Pledge, N., Kemp, A., Rozefelds, A., 1992. Australian Cretaceous terrestrial faunas and floras: biostratigraphic and biogeographic implications. Cretaceous Research 13, 207-262.

Dickie, I.A., Holdaway, R.J., 2011. Podocarp roots, mycorrhizas, and nodules. In: Turner, B.L., Cernusak, L.A. (Eds.), Ecology of the Podocarpaceae in Tropical Forests. Smithsonian Contributions to Botany, No. 95. Smithsonian Institution Scholarly Press, Washington, D.C., pp. 175-187.

Doludenko, M.P., Reymanowna, M., 1978. Frenelopsis harrisii sp. nov. from the Cretaceous of Tajikistan, USSR. Acta Palaeobotanica 19, 3-9.

Douglas, J.G., 1969. The Mesozoic floras of Victoria. Parts 1 and 2. Geological Survey of Victoria Memoirs 28, 1-310.

Douglas, J.G., 1973. The Mesozoic floras of Victoria. Part 3. Geological Survey of Victoria Memoirs 29, 1-185.

Douglas, J.G., 1985. The Albian extinctions in the great Aust-Antarctic Trough. In: Cooper, R. (Ed.), Hornibrook Symposium, Christchurch New Zealand. New Zealand Geological Survey Record, 9, pp. 38-40.

Drinnan, A.N., Chambers, T.C., 1986. Flora of the Lower Cretaceous Koonwarra Fossil Beds (Korumburra Group), South Gippsland, Victoria. Association of Australasian Palaeontologists Memoirs 3, 1-77.

Du, B., Sun, B., Ferguson, D.K., Yan, D., Dong, C., Jin, P., 2013. Two Brachyphyllum species from the Lower Cretaceous of Jiuquan Basin, Gansu Province, NW China, and their affinities and palaeoenvironmental implications. Cretaceous Research 41, 242-255.

Duddy, I.R., 2003. Mesozoic. In: Birch, W.D. (Ed.), Geology of Victoria. Geological Society of Australia Special Publication, 23, pp. 239-286.

Edwards, A.B., Baker, G., 1943. Jurassic arkose in southern Victoria. Proceedings of the Royal Society of Victoria 55, 195-228.

Escapa, I., Cúneo, R., Axsmith, B., 2008. A new genus of the Cupressaceae (sensu lato) from the Jurassic of Patagonia: implications for conifer megasporangiate cone homologies. Review of Palaeobotany and Palynology 151, 110-122.

Escapa, I.H., Rothwell, G.W., Stockey, R.A., Cúneo, N.R., 2012. Seed cone anatomy of Cheirolepidiaceae (Coniferales): reinterpreting Pararaucaria patagonica Wieland. American Journal of Botany 99, 1058-1068.

Escapa, I.H., Cúneo, N.R., Rothwell, G., Stockey, R.A., 2013. Pararaucaria delfueyoi sp. nov, from the Late Jurassic Cañadón Calcáreo Formation, Chubut, Argentina: insights into the evolution of the Cheirolepidiaceae. International Journal of Plant Sciences $174,458$.

Fairon-Demaret, M., Hilton, J., Berry, C.M., 1999. Surface preparation of macrofossils (dégagement). In: Jones, T.P., Rowe, N.P. (Eds.), Fossil Plants and Spores: Modern Techniques. The Geological Society of London, Bath, pp. 33-35.

Farjon, A., 2005. Monograph of Cupressaceae and Sciadopitys. Royal Botanic Gardens, Kew (648 pp.).

Featherstone, P., Aigner, T., Brown, L., King, M., Leu, W., 1991. Stratigraphic modelling of the Gippsland Basin. APEA Journal 31, 105-114

Ferguson, K.M., Gregory, R.T., Constantine, A., 1999. Lower Cretaceous (Aptian-Albian) secular changes in the oxygen and carbon isotope record from high palaeolatitude, fluvial sediments, southeastern Australia: comparisons to the marine record. Geological Society of America, Special Paper 332, 59-72.

Filatoff, J., 1975. Jurassic palynology of the Perth Basin. Palaeontographica Abteilung B $154,1-113$.

Francis, J.E., 1983. The dominant conifer of the Jurassic Purbeck Formation, England. Palaeontology 26, 277-294.

Francis, J.E., 1984. The seasonal environment of the Purbeck (Upper Jurassic) fossil forests. Palaeogeography, Palaeoclimatology, Palaeoecology 48, 285-307.

Gleadow, A.J.W., Duddy, I.R., 1981. Early Cretaceous volcanism and the early breakup history of southeastern Australia: evidence from fission track dating of volcaniclastic sediments. In: Creswell, M.M., Vella, P. (Eds.), Gondwana Five. A.A. Balkema, Rotterdam, pp. 295-300.

Gomez, B., Martín-Closas, C., Méon, H., Thévenard, F., Barale, G., 2001. Plant taphonomy and palaeoecology in the lacustrine Uña delta (Late Barremian, Iberian Ranges, Spain). Palaeogeography, Palaeoclimatology, Palaeoecology 170, 133-148.

Gomez, B., Martínez-Delclòs, X., Bamford, M., Philippe, M., 2002a. Taphonomy and palaeoecology of plant remains from the oldest African Early Cretaceous amber locality. Lethaia 35, 300-308.

Gomez, B., Martín-Closas, C., Barale, G., Thévenard, F., Guignard, G., 2002b. Frenelopsis (Coniferales: Cheirolepidiaceae) and related male organ genera from the Lower Cretaceous of Spain. Palaeontology 45, 997-1036.

Gomez, B., Bamford, M., Martinez-Delclòs, X., 2002c. Lower cretaceous plant cuticles and amber (Kirkwood Formation, South Africa). Comptes Rendus Palevol 1, 83-87.

Gould, R.E., 1980. The coal-forming flora of the Walloon Coal Measures. Australian Coal Geology 1, 83-105.

Gradstein, F.M., Ogg, J.G., Schmitz, M., Ogg, G., 2012. The Geologic Time Scale 2012. Elsevier, Amsterdam (1176 pp.).

Green, P.F., Crowhurst, P.V., Duddy, I.R., 2004. Integration of AFTA and (U-Th)/He thermochronology to enhance the resolution and precision of thermal history reconstruction in the Anglesea-1 well, Otway Basin, SE Australia. In: Boult, P.J., Johns, D.R., Lang, S.C. (Eds.), Eastern Australian Basins Symposium II. Petroleum Exploration Society of Australia Special Publication, Melbourne, pp. 117-131. 
Groves, R.H., 1981. Australian Vegetation. Cambridge University Press, Cambridge (449 pp.).

Guignard, G., Thevenard, F., van Konijnenburg-van Cittert, J.H.A., 1998. Cuticle ultrastructure of the cheirolepidiaceous conifer Hirmeriella muensteri (Schenk) Jung. Review of Palaeobotany and Palynology 104, 115-141.

Harms, R.J., Bennell, T.M., 1999. Victorian Petroleum data packages. Documentation Version 0.5 k. Department of Natural Resources and Environment (CD).

Harris, T.M., 1979. The Yorkshire Jurassic Flora. V. Coniferales. British Museum of Natural History, London (166 pp.).

He, W., Sun, B., Liu, Y.-S., 2012. Fokienia shengxianensis sp. nov. (Cupressaceae) from the late Miocene of eastern China and its paleoecological implications. Review of Palaeobotany and Palynology 176-177, 24-34.

Helby, R., Morgan, R., Partridge, A.D., 1987. A palynological zonation of the Australian Mesozoic. Association of Australasian Palaeontologists Memoirs 4, 1-94.

Hill, R.S., Pole, M.S., 1992. Leaf and shoot morphology of extant Afrocarpus, Nageia and Retrophyllum (Podocarpaceae) species, and species with similar leaf arrangement from Tertiary sediments in Australasia. Australian Systematic Botany 5, 337-358.

Hill, K.A., Finlayson, D.M., Hill, K.C., Cooper, G.T., 1995a. Mesozoic tectonics of the Otway Basin region: the legacy of Gondwana and the active Pacific margin-a review and ongoing research. APEA Journal 35, 467-493.

Hill, K.C., Hill, K.A., Cooper, G.T., O'Sullivan, A.J., O'Sullivan, P.B., Richardson, M.J., 1995b. Inversion around the Bass Basin, SE Australia. In: Buchanan, J.G., Buchanan, P.G. (Eds.), Basin Inversion. Geological Society Special Publication, 88, pp. 525-547.

Hueber, F.M., Watson, J., 1988. The unusual Upper Cretaceous conifer Androvettia from Eastern U.S.A. Botanical Journal of the Linnean Society 2, 117-133.

Jansson, I.M., McLoughlin, S., Vajda, V., Pole, M., 2008. An Early Jurassic flora from the Clarence-Moreton Basin, Australia. Review of Palaeobotany and Palynology 150, 5-21.

Knobloch, E., 1971. Neue Pflanzenfunde aus dem böhmischen und mährischen Cenoman Neues Jahrbuch für Geologie und Paläontologie, Abhandlungen 139, 43-56.

Krassilov, V.A., 1987. Palaeobotany of the Mesophyticum: state of the art. Review of Palaeobotany and Palynology 50, 231-254.

Kunzmann, L., 2010. Geinitzia reichenbachii (Geinitz, 1842) Hollick and Jeffrey, 1909 and Sedites rabenhorstii Geinitz, 1842 (Pinopsida; Late Cretaceous) reconsidered and redescribed. Review of Palaeobotany and Palynology 159, 123-140.

Kunzmann, L., Mohr, B.A.R., Bernardes-de-Oliveira, M.E.C., Wilde, V., 2006. Gymnosperms from the Early Cretaceous Crato Formation (Brazil). II. Cheirolepidiaceae. Fossil Record-Mitteilungen aus dem Museum für Naturkunde 9, 213-225.

Kunzmann, L., Kvaček, Z., Mai, D.H., Walther, H., 2009. The genus Taxodium (Cupressaceae) in the Palaeogene and Neogene of Central Europe. Review of Palaeobotany and Palynology 153, 153-183.

Kvaček, J., 2000. Frenelopsis alata and its microsporangiate and ovuliferous reproductive structures from the Cenomanian of Bohemia (Czech Republic, Central Europe). Review of Palaeobotany and Palynology 112, 51-78.

Kvaček, Z., Manchester, S.R., Schorn, H.E., 2000. Cones, seeds, and foliage of Tetraclinis salicornioides (Cupressaceae) from the Oligocene and Miocene of Western North America: a geographic extension of the European Tertiary species. International Journal of Plant Sciences 161, 331-344.

Labandeira, C.C., Kvaček, J., Mostovski, M.B., 2007. Pollination drops, pollen, and insect pollination of Mesozoic gymnosperms. Taxon 56, 663-695.

Leng, Q., Yang, H., Yang, Q., Zhou, J., 2001. Variation of cuticle micromorphology of Metasequoia glyptostroboides (Taxodiaceae). Botanical Journal of the Linnean Society $136,207-219$

Lowry, D.C., 1988. Alternative Cretaceous history of the Gippsland Basin. Australian Journal of Earth Sciences 35, 181-194

Lowry, D.C., Longley, I.M., 1991. A new model for the mid-Cretaceous structural history of the northern Gippsland Basin. APEA Journal 31, 143-153.

Ma, Q.-W., Ferguson, D.K., Li, F.-L., Li, C.-S., 2009. Leaf epidermal structures of extant plants of Cunninghamia and Taiwania (Cupressaceae sensu lato) and their taxonomic application. Review of Palaeobotany and Palynology 155, 15-24.

Maheshwari, H.K., 2005. Family Hirmeriellaceae nom. nov. Geophytology 35, 101-102.

Mallett, C.W., Holdgate, G.R., 1985. Subsurface Neogene stratigraphy of Nepean Peninsula, Victoria. Special Publication of the South Australian Department of Mines and Energy $5,233-245$.

Mays, C., 2011. Mid-Cretaceous Greenhouse Environments and Floral Ecosystems of the South Polar Region $\left(75-80^{\circ} \mathrm{S}\right)$ :. The Tupuangi Formation, Chatham Islands, Zealandia. $\mathrm{PhD}$ thesis, Monash University, Melbourne 378 pp. (unpublished).

McIver, E.E., 2001. Cretaceous Widdringtonia Endl. (Cupressaceae) from North America. International Journal of Plant Science 162, 937-961.

McLoughlin, S., 1996. Early Cretaceous macrofloras of Western Australia. Records of the Western Australian Museum 18, 19-65.

McLoughlin, S., Hill, R.S., 1996. The succession of Western Australian Phanerozoic floras. In: Gondwanan Heritage: past, present and future of the Western Australian biota. In: Hopper, S.D., Chappill, J.A., Harvey, M.S., George, A.S. (Eds.), Proceedings of the Conference on Systematics, Evolution and Conservation of the Western Australian Biota, Perth, 1993. Surrey Beatty, Sydney, pp. 61-80.

McLoughlin, S., McNamara, K., 2001. Ancient Floras of Western Australia. Publication of the Department of Earth and Planetary Sciences, Western Australian Museum, Perth (42 pp.)

McLoughlin, S., Pott, C., 2009. The Jurassic flora of Western Australia. GFF 131, 113-136.

McLoughlin, S., Drinnan, A.N., Rozefelds, A.C., 1995. The Cenomanian flora of the Winton Formation, Eromanga Basin, Queensland, Australia. Memoirs of the Queensland Museum 38, 273-313.

McLoughlin, S., Tosolini, A.M.P., Drinnan, A.N., 2000. Revision of an Early Cretaceous macroflora from the Maryborough Formation, Maryborough Basin, Queensland, Australia. Memoirs of the Queensland Museum 45, 483-503.
McLoughlin, S., Tosolini, A.-M., Nagalingum, N., Drinnan, A.N., 2002. The Early Cretaceous (Neocomian) flora and fauna of the lower Strzelecki Group, Gippsland Basin, Victoria, Australia. Association of Australasian Palaeontologists Memoirs 26, 1-144.

McLoughlin, S., Carpenter, R.J., Jordan, G.J., Hill, R.S., 2008. Seed-ferns survived the end-Cretaceous mass-extinction in Tasmania. American Journal of Botany 95 , 465-471.

McLoughlin, S., Pott, C., Elliott, D., 2010. The Winton Formation flora (AlbianCenomanian, Eromanga Basin): implications for vascular plant diversification and decline in the Australian Cretaceous. Alcheringa 34, 303-323.

McLoughlin, S., Carpenter, R.J., Pott, C., 2011. Ptilophyllum muelleri (Ettingsh.) comb. nov. from the Oligocene of Australia: last of the Bennettitales? International Journal of Plant Sciences 172, 574-585.

McLoughlin, S., Jansson, I.M., Vajda, V., 2014. Megaspore and microfossil assemblages reveal diverse herbaceous lycophytes in the Australian Early Jurassic flora. Grana 53. http://dx.doi.org/10.1080/00173134.2013.848234 (000-000, in press).

Medwell, L.M., 1954a. A review and revision of the flora of the Victorian Lower Jurassic. Proceedings of the Royal Society of Victoria 65, 63-111.

Medwell, L.M., 1954b. Fossil plants from Killara, near Casterton. Proceedings of the Royal Society of Victoria 66, 17-23.

Mendes, M.M., Dinis, J.L., Gomez, B., Pais, J., 2010. Reassessment of the cheirolepidiaceous conifer Frenelopsis teixeirae Alvin et Pais from the Early Cretaceous (Hauterivian) of Portugal and palaeoenvironmental considerations. Review of Palaeobotany and Palynology $161,30-42$

Mildenhall, D.C., 1994. Palynological reconnaissance of Early Cretaceous to Holocene sediments, Chatham Islands, New Zealand. Institute of Geological and Nuclear Sciences Monograph 7, 1-206.

Morgan, R., Alley, N.F., Rowett, A.I., White, M.R., 1995. Biostratigraphy. In: Basin, Otway, Morton, J.G.G., Drexel, J.F. (Eds.), The Petroleum Geology of South Australia. Mines and Energy South Australia, Report Book 95/12, vol. 1, pp. 95-101.

Morrison, T.M., English, D.A., 1967. The significance of mycorrhizal nodules of Agathis australis. New Phytologist 66, 245-250.

Mosse, B., 1973. Advances in the study of VA-mycorrhiza. Annual Review of Phytopathology 11, 1711-194

Msaky, E.S., 2011. Middle Jurassic-earliest Late Cretaceous palynofloras, coastal Tanzania, Pt. 2. Palaeontographica Abteilung B 209, 144-151.

Nagalingum, N.S., Drinnan, A.N., McLoughlin, S., 2005. A new Neocomian conifer species, Bellarinea richardsii, from the lower Strzelecki Group, Gippsland Basin, Victoria. Proceedings of the Royal Society of Victoria 117, 1-12.

Norvick, M.S., Burger, D., 1975. Palynology of the Cenomanian of Bathurst Island, Northern Territory, Australia. Bureau of Mineral Resources Geology and Geophysics Bulletin 151, 1-169.

Norvick, M.S., Smith, M.A., Power, M.R., 2001. The plate tectonic evolution of eastern Australasia guided by the stratigraphy of the Gippsland Basin. In: Hill, K.C., Bernecker, T. (Eds.), Eastern Australasian Basins Symposium, A Refocused Energy Perspective for the Future. Petroleum Exploration Society of Australia, Special Publication, Melbourne, pp. 15-23.

Okubo, A., Kimura, T., 1991. Cuticular study on the Cupressinocladus leafy-shoots from the Lower Cretaceous Choshi Group. Bulletin of the National Science Museum, Tokyo, C 17, 91-109.

Paclt, J., 2011. Proposal to conserve the name Cheirolepidaceae (fossil Coniferales). Taxon $60,1219$.

Partridge, A.D., 2006. Jurassic-Early Cretaceous spore-pollen and dinocyst zonations for Australia. In: Australian Mesozoic and Cenozoic Palynology Zonations-updated to the 2004 Geologic Time Scale. Monteil, E. (Coord.), Geoscience Australia Record 2006/23 (CD only)

Perez Loinaze, V.S., Archangelsky, S., Cladera, G., 2012. Palynostratigraphic study of the Early Cretaceous Río Mayer and Kachaike formations at the Quebrada El Moro Section, Austral Basin, southwestern Argentina. Cretaceous Research 34, 161-171.

Perincek, D., Cockshell, C.D., 1995. The Otway Basin: Early Cretaceous rifting to Neogene inversion. APEA Journal 35, 451-466.

Peters, M.D., Christophel, D.C., 1978. Austrosequoia wintonensis, a new taxodiaceous cone from Queensland, Australia. Canadian Journal of Botany 56, 3119-3128.

Peyrot, D., Barrón, E., Comas-Rengifo, M.J., Thouand, E., Tafforeau, P., 2007. A confocal laser scanning and conventional wide field light microscopy study of Classopollis from the Toarcian-Aalenian of the Fuentelsaz section (Spain). Grana 46, 217-226.

Pflug, H.D., 1953. Zur Entstehung und Entwicklung des angiospermiden pollens in de Erdgeschichte. Palaeontographica Abteilung B 95, 60-171.

Pocock, S.J., Jansonius, J., 1961. The pollen genus Classopollis Pflug, 1953. Micropaleontology $7,439-449$

Pole, M.S., 2000. Mid-Cretaceous conifers from the Eromanga Basin, Australia. Australian Systematic Botany 13, 153-197.

Pole, M., Philippe, M., 2010. Cretaceous plant fossils of Pitt Island, the Chatham group, New Zealand. Alcheringa 34, 231-263.

Quattrocchio, M.E., Volkheimer, W., Borromei, A.M., Martínez, M.A., 2011. Changes of the palynobiotas in the Mesozoic and Cenozoic of Patagonia: a review. Biological Journal of the Linnean Society 103, 380-396.

Raine, J.I., Mildenhall, D.C., Kennedy, E.M., 2011. New Zealand fossil spores and pollen: an illustrated catalogue, 4th edition. GNS Science Miscellaneous Series, no. 4 (http: http://data.gns.cri.nz/sporepollen/index.htm (accessed 24.10.2013)).

Rees, P.M., Cleal, C.J., 2004. Lower Jurassic floras from Hope Bay and Botany Bay, Antarctica. Special Papers in Palaeontology 72, 1-90.

Reiser, R.F., Williams, A.J., 1969. Palynology of the Lower Jurassic sediments of the northern Surat Basin, Queensland. Geological Survey of Queensland Publication 339 Palaeontological Paper, 15, pp. 1-24.

Reissinger, A., 1950. Die "Pollenanalyse" ausgedehnt auf alle sedimentgesteine der Geologischen Vergangenheit. Palaeontographica Abteilung B 90, 90-126. 
Remy, W., Taylor, T.N., Haas, H., Kerp, H., 1994. Four hundred-million-year-old vesicular arbuscular mycorrhizae. Proceedings of the National Academy of Science 91, 11841-11843.

Reymanówna, M., Watson, J., 1976. The genus Frenelopsis Schenk and the type species Frenelopsis hoheneggeri (Ettingshausen) Schenk. Acta Palaeobotanica 17, 17-26.

Reyre, Y., 1970. Stereoscan observations on the pollen genus Classopollis Pflug 1953. Paleontology 13, 303-322.

Rothwell, G.W., Mapes, G., Hilton, J., Hollingworth, N.T., 2007. Pollen cone anatomy of Classostrobus crossii sp. nov. (Cheirolepidiaceae). International Journal of Coal Geology 69, 55-67.

Rothwell, G.W., Stockey, R.A., Mapes, G., Hilton, J., 2011. Structure and relationships of the Jurassic conifer seed cone Hughmillerites juddii gen. et comb. nov.: implications for the early evolution of Cupressaceae. Review of Palaeobotany and Palynology 164, 45-59.

Schwendemann, A.B., Decombeix, A.-L., Taylor, T.N., Taylor, E.L., Krings, M., 2011. Morphological and functional stasis in mycorrhizal root nodules as exhibited by a Triassic conifer. Proceedings of the National Academy of Science 108, 13630-13634.

Serbet, R., Bomfleur, B., Rothwell, G.W., 2013. Cunninghamia taylorii sp. nov., a structurally preserved cupressaceous conifer from the Upper Cretaceous (Campanian) Horseshoe Canyon Formation of western North America. International Journal of Plant Sciences 174, 471-488

Seward, A.C., 1904. On a collection of Jurassic plants from Victoria. Records of the Geological Survey of Victoria 1, 155-211.

Shi, G.L., Zhou, Z.Y., Xie, Z.M., 2011. Cupressus foliage shoots and associated seed cones from the Oligocene Ningming Formation of Guangxi, South China. Review of Palaeobotany and Palynology 166, 325-334.

Shu, O., Deng Xi-Guang, D., Shen, Y., Xiang-Shen, Z., Xiao-Han, L., 2000. Late Triassic plant microfossils from Miers Bluff Formation of Livingston Island, South Shetland Islands, Antarctica. Antarctic Science 12, 217-228.

Slankis, V., 1974. Soil factors influencing formation of Mycorrhizae. Annual Review of Phytopathology 12, 437-457.

Smith, G.C., 1988. Oil and gas. In: Douglas, J.G., Ferguson, J.A. (Eds.), Geology of Victoria. Geological Society of Australia, Melbourne, pp. 514-546.

Spratt, E.R., 1912. The formation and physiological significance of root nodules in the Podocarpineae. Annals of Botany 26, 801-814.

Srinivasan, V., 1995. Conifers from the Puddledock locality (Potomac Group, Early Cretaceous) in eastern North America. Review of Palaeobotany and Palynology 89, 257-286.

Srivastava, S.K., 1976. The fossil pollen genus Classopollis. Lethaia 9, 437-457.

Sucerquia, P., Bernardes-de-Oliveira, M.E.C., Moreno-Sánchez, M., 2008. Frenelopsid conifers in the northern South America and its stratigraphic, paleogeographic and paleoclimatic significance. IPC-XII/IOPC-VIII Bonn, Germany 2008 Abstract Volume. Terra Nostra, 2008/2, p. 271.

Takhtajan, A.L., 1963. Gymnosperms and angiosperms. Osnovy Paleontologii 15, 1-743 (In Russian).

Taylor, T.N., Alvin, K.L., 1984. Ultrastructure and development of Mesozoic pollen: Classopollis. American Journal of Botany 71, 575-587.

Tosolini, A.-M.P., 2001. Early Cretaceous Plant Biofacies of the Otway and Strzelecki Groups, Victoria. University of Melbourne, School of Botany (PhD thesis, 292 pp.).

Tosolini, A.-M.P., Pole, M., 2010. Insect and clitellate annelid traces in mesofossil assemblages from the Cretaceous of Australasia. Alcheringa 34, 397-419.

Tosolini, A.-M.P., McLoughlin, S., Drinnan, A.N., 1999. Stratigraphy and fluvial sedimentary facies of the Neocomian lower Strzelecki Group, Gippsland Basin, Victoria. Australian Journal of Earth Sciences 46, 951-970.

Tosolini, A.-M.P., McLoughlin, S., Drinnan, A.N., 2002. Early Cretaceous megaspore assemblages from southeastern Australia. Cretaceous Research 23, 807-844.

Traverse, A., 2004. Proposal to conserve the fossil pollen morphogeneric name Classopollis against Corollina and Circulina. Taxon 53, 847-848.

Turner, S., Bean, L.B., Dettmann, M., McKellar, J., McLoughlin, S., Thulborn, T., 2009 Australian Jurassic sedimentary and fossil successions: current work and future prospects for marine and non-marine correlation. GFF 131, 49-70.

Upchurch Jr., G.R., Doyle, J.A., 1981. Paleoecology of the conifers Frenelopsis and Pseudofrenelopsis (Cheirolepidiaceae) from the Cretaceous Potomac Group of Maryland and Virginia. In: Romans, R.C. (Ed.), Geobotany II. Plenum Press, New York, pp. 167-202

Vajda, V., McLoughlin, S., 2004. Fungal proliferation at the Cretaceous-Tertiary boundary. Science 303, 1489

Vajda, V., Raine, J.I., Hollis, C.J., 2001. Indication of global deforestation at the CretaceousTertiary boundary by New Zealand fern spike. Science 294, 1700-1702.

Vakhrameev, V.A., 1970. Range and paleoecology of the Mesozoic conifers, the Cheirolepidiaceae. [Translated from: Zakonomernosti rasprostranenioya i paleoekologiya mezozoyskikh khvoynykh Cheirolepidiaceae. Paleontologicheskiy Zhurnal 4, 19-34.]. Paleontological Journal 4, 12-25. van der Ham, R.W.J.M., van Konijnenburg-van Cittert, J.H.A., Dortangs, R.W., Herngreen, G.F.W., van der Burgh, J., 2003. Brachyphyllum patens (Miquel) comb. nov. (Cheirolepidiaceae?); remarkable conifer foliage from the Maastrichtian type area (Late Cretaceous, NE Belgium, SE Netherlands). Review of Palaeobotany and Palynology 127, 77-97.

van Konijnenburg-van Cittert, J.H.A., 1987. New data on Pagiophyllum maculosum Kendall and its male cone from the Jurassic of North Yorkshire. Review of Palaeobotany and Palynology 51, 95-105.

Veevers, J.J., Powell, C. McA, Roots, S.R., 1991. Review of seafloor spreading around Australia. I. Synthesis of the patterns of spreading. Australian Journal of Earth Sciences 38, 373-389.

Villar de Seoane, L., 1998. Comparative study of extant and fossil conifer leaves from the Baquero Formation (Lower Cretaceous), Santa Cruz Province, Argentina. Review of Palaeobotany and Palynology 99, 247-263.

Volkheimer, W., Rauhut, O.W.M., Quattrocchio, M., Martínez, M.A., 2008. Jurassic paleoclimates in Argentina, a review. Revista de la Asociación Geológica Argentina 63, 549-556.

Wagstaff, B.E., McEwen Mason, J., 1989. Palynological dating of Lower Cretaceous coastal vertebrate localities, Victoria, Australia. National Geographic Research 5, 54-63.

Wagstaff, B.E., Constantine, A.E., McEwen Mason, J., 1997. Palynological dating of Strzelecki Group sediments associated with Lower Cretaceous labyrinthodont fossils, Victoria, Australia. Appendix. In: Warren, A., Rich, T.H., Vickers-Rich, P. (Eds.), The Last Last Labyrinthodonts? . Palaeontographica, 247A, pp. 19-22.

Wagstaff, B.E., Gallagher, S.J., Trainor, J.K., 2012. A new subdivision of the Albian spore-pollen zonation of Australia. Review of Palaeobotany and Palynology $171,57-72$.

Walkom, A.B., 1921. Mesozoic floras of New South Wales. Part 1-fossil plants from Cockabutta Mountain and Talbragar. Geological Survey of New South Wales, Palaeontology, Memoir 12, 1-21.

Warrington, G., 1996. Triassic spores and pollens. In: Jansonius, J., McGregor, D.C. (Eds.), Palynology: Principles and Applications. American Association of Stratigraphic Palynologists Foundation, 2, pp. 755-766.

Watson, J., 1974. Manica: a new fossil conifer genus. Taxon 23, 428.

Watson, J., 1977. Some Lower Cretaceous conifers of the Cheirolepidiaceae from the U.S.A. and England. Palaeontology 20, 715-749.

Watson, J., 1983. A new species of the conifer Frenelopsis from the Cretaceous of Sudan. Botanical Journal of the Linnean Society 86, 161-167.

Watson, J., 1988. The Cheirolepidiaceae. In: Beck, C.B. (Ed.), Origin and Evolution of Gymnosperms. Columbia University Press, New York, pp. 382-447.

Watson, J., Alvin, K.L., 1999. The cheirolepidiaceous conifers Frenelopsis occidentalis Heer and Watsoniocladus valdensis (Seward) in the Wealden of Germany. Cretaceous Research 20, 315-326.

Watson, J., Harrison, N.A., 1998. Abietites linkii (Römer) and Pseudotorellia heterophylla Watson: coniferous or ginkgoalean? Cretaceous Research 19, 239-278.

Wellman, C.H., Axe, L., 1999. Extracting plant mesofossils and megafossils by bulk maceration. In: Jones, T.P., Rowe, N.P. (Eds.), Fossil Plants and Spores: Modern Techniques. Geological Society, London, pp. 11-14.

Whang, S.S., Hill, R.S., 1999. Late Palaeocene Cupressaceae macrofossils at Lake Bungarby, New South Wales. Australian Systematic Botany 12, 241-254.

Wilf, P., Little, S.A., Iglesias, A., Zamaloa, M.C., Gandolfo, M.A., Cúneo, N.R., Johnson, K.R., 2009. Papuacedrus (Cupressaceae) in Eocene Patagonia: a new fossil link to Australasian rainforests. American Journal of Botany 96, 2031-2047.

Wright, I.J., Reich, P.B., Westoby, M., 2001. Strategy shifts in leaf physiology, structure and nutrient content between species of high and low-rainfall and high- and low-nutrient habitats. Functional Ecology 15, 423-434.

Xiang, Q.P., Farjon, A., 2003. Cuticle morphology of a newly discovered conifer, Xanthocyparis vietnamensis (Cupressaceae), and a comparison with some of its nearest relatives. Botanical Journal of the Linnean Society 143, 315-322.

Yang, X.J., Deng, S.H., Li, W.B., 2006. A new cheirolepidiaceous conifer from the Early Jurassic of the Junggar Basin, northern Xinjiang and its paleoclimatic implications. Progress in Natural Science 16, 231-235.

Yang, X.-J., Guignard, G., Thévenard, F., Wang, Y.-D., Barale, G., 2009. Leaf cuticle ultrastructure of Pseudofrenelopsis dalatzensis (Chow et Tsao) Cao ex Zhou (Cheirolepidiaceae) from the Lower Cretaceous Dalazi Formation of Jilin, China. Review of Palaeobotany and Palynology 153, 8-18.

Yao, X., Zhou, Z., Zhang, B., 1998. Reconstruction of the Jurassic conifer Sewardiodendron laxum (Taxodiaceae). American Journal of Botany 85, 1289-1300.

Zhou, Z.Y., 1995. On some Cretaceous pseudofrenelopsids with a brief review of cheirolepidiaceous conifers in China. Review of Palaeobotany and Palynology 84, 419-438. 